\title{
The Clay Paw Burial Rite of the Åland Islands and Central Russia: A Symbol in Action
}

\author{
Johan Callmer
}

\begin{abstract}
The clay paw burial rite is a special feature of the Aland Islands. It is introduced already in the seventh century shortly after a marked settlement expansion and considerable cultural changes. The rite may be connected with groups involved in beaver hunting since the clay paws in many cases can be zoologically classified as paws of beavers. On the Åland Islands only minor parts of the population belong to this group. Other groups specialized in contacts with the Finnish mainland. The clay paw group became involved in hunting expeditions further and further east and in the ninth century some of the members established themselves in three or four settlements on the middle Volga. There is a later expansion into the area between the Volga and the Kljaz'ma. The clay paw burial rite gives us an unique possibility to identify a specific Scandinavian population group in European Russia in the ninth and tenth centuries. With the introduction of Christian and semi-Christian burial customs ca. A.D. 1000 we cannot archaeologically distinguish this group any more but some historical sources could indicate its existence throughout the eleventh cetury in Russia. The clay paw burial rite brings to the fore questions about local variations and special elements in the Pre-Christian Scandinavian religion. Possibly elements of Finno-ugric religious beliefs had a connection with the development of this rite.
\end{abstract}

Johan Callmer, Institute of Archaeology, Krafts torg 1, S-22350 Lund, Sweden.

Burial customs may be a relevant field of research for solving different kinds of problems. Questions concerning religion, mythology and magic are obvious startingpoints for studies of burial custom data. Sometimes, but not always, there is also reason to study the mortuary practices in order to come closer to an understanding of social systems and social aggregates. In a limited number of cases grave data may also contribute to an understanding of large-scale processes of social change. Further grave data can sometimes give us a basis to discuss the complicated questions connected with the spatial dislocation of population groups over great distances, much greater than the traditional home range. The clay paw burial rite of the Alland Islands and central Russia in a most striking manner can contribute to several of the aspects mentioned here and especially to the latter ones.

The clay paw burial rite was first described by the important nineteenth-century amateur archaeologist A.S. Ouvaroff in connection with the publication of the results of large-scale excavations of central Russian tumulus cemeteries from the early medieval period. In a number of cremation graves in the Suzdal' and Rostov areas hand- or rather pawlike clay objects have been found. The paws were regarded by Ouvaroff as religiously motivated 
objects forming part of the local Merian (i.e. Finnish) burial rite. The paws or, as Ouvaroff suggested, hands could have helped the deceased on his journey to the other side (Ouvaroff 1875:93-94). The Finnish archaeologist A. Hackman made clear in 1902 that the clay paws could be found in Viking Age graves both in Russia and on Aland. Hackman's explanation of this observation was that the rite was brought to Aland from central Russia in connection with intensive contacts between Scandinavia and eastern Europe in the Viking Age (Hackman 1902:40) (Fig. 1).

The first scholar to devote a comprehensive article to the problem of the clay paws was E. Kivikoski, who published in 1934 the then known graves with clay paws on $\AA$ land (Kivikoski 1934). She remarked that the paws were exclusively made for the occasion of the burial ceremony, that the paws had a ritual significance, and that they have a rather long history on Åland. She did not express any uncertainty about the close connection between the finds on Alland and those in Russia, but the question of the origin of the rite was only touched upon with caution and

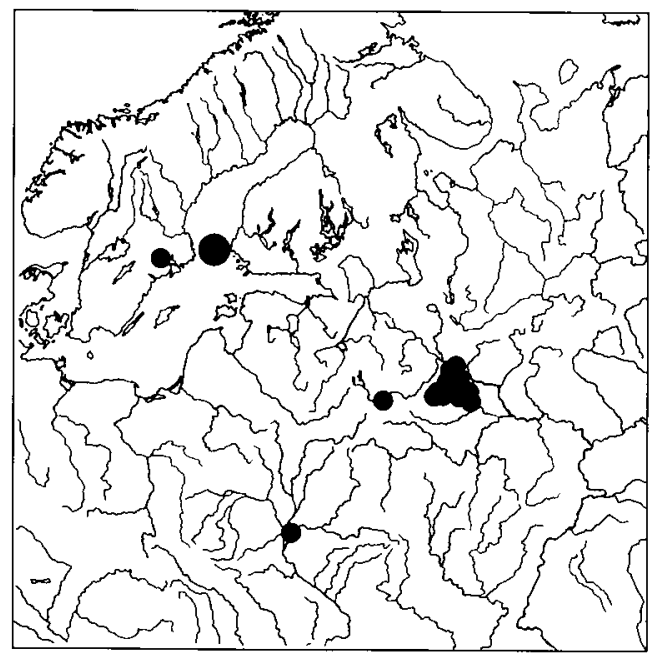

Fig. I. The distribution of clay paws in seventh- to tenth-century graves in northern, northeastern and eastern Europe. she expressed hope that forthcoming new archaeological material would clarify the problem (ibid: 390-1). In the article Kivikoski dwelled upon the crucial question of the zoological classification of the paws and suggested, on the basis of an expert report, that some paws were beaver paws and others bear paws. There was also one clay paw which looked like a human hand and one which was interpreted as a dog's paw (ibid: $38 \mathrm{I}-4$ ). A more definite zoological interpretation of the clay paws, as bear paws although made by an archaeologist, was the framework for a discussion by Voronin of the connection with the bear cult in northern and northeastern Europe and further east in northern Asia (Voronin 1941). It was also suggested that the clay paw rite had developed independently in the two different regions. This is a typical Marrist argument and very characteristic of Soviet archaeology of the 1930s and 1940s. In the same volume that contains Voronin's article, Ja. Stankeviç made some analogous commentaries and declared that clay paws occur among a number of different ethnic groups, e.g. among the Merians and among other peoples of the Volga region. As far as we know today, the latter statement was incorrect. Stankeviç also noted that the paws were found in cremations and that they were usually deposited close to the urns, which, in fact, is exactly the same characterization of the position of the paws on Åland, as Kivikoski observed (Stankeviç 1941:66-8). In her ingenious survey of the Late Iron Age and early medieval period of the mesopotamia region of the Volga and the Oka, E.I. Gorjunova suggests interpretations similar to Voronin's but she also strongly stresses the Merian character of the rite (Gorjunova 1961:147-8).

A most important step forward in the study of the clay paws and their significance was the publication by a Soviet research team, headed by M.V. Fechner, of the results of large-scale excavations of a great number of ninth- and tenth-century graves in three 
cemeteries near Jaroslavl' on the Volga (Jaroslavskoe Povold'e 1963). A number of earlier excavations of the same cemeteries were also republished or published for the first time. In no less than 71 excavated barrows, paws had been collected. A zoological examination of this material, most of which was new, was interpreted by Fechner as evidence that the majority of the paws should be understood as reproductions in clay of beaver paws. Also other observations, both of artefacts and of the osteological material from the cremations, suggested the importance of the beaver. The interpretation of some clay paws as reproductions of bear paws was not excluded. The magical and totemistic nature of the paws was also stressed (Fechner 1963).

In 1965 Kivikoski returned to the question of the paws, greatly inspired by Fechner's publication. She now clearly takes the position that the clay paw rite originates on Alland. A renewed consideration of the zoological attribution of the paw finds of Alland strongly suggested conclusions similar to those reached by the Soviet scholar (Kivikoski 1965).

The question of the origin of the clay paw rite was not touched upon by Fechner, but a new interpretation was put forward a little later by P.N. Tret jakov. In a work on the origin of Russia, which is full of interesting suggestions, he maintains that the finds of clay paws in Russia and on Aland were connected with a bear cult among the Vepsians who occupied a wide region between the Ladoga and the upper Volga. It is suggested that the Vepsians had a grave ritual, the traces of which cannot be found with archaeological techniques (graves in trees); and that is why no finds have been made which more directly connect the central Russian and the $\AA$ landic finds (Tret'jakov 1970:127).

Among Soviet scholars, V.I. Dubov has most recently in detail occupied himself with the interpretation of the clay paws which, together with clay rings also found in central Russian graves, he connects with a hypothetical, local north Merian grave rite (Dubov
1982:20-28, 1984). Fechner's stress on the likeness of the paws to beaver paws, as well as several other arguments for a special importance of the beaver, are strongly criticized. Dubov agrees wholeheartedly with Voronin's main idea that the clay paws are part of the bear cult, and the totemistic beliefs behind the rite are stressed. The occurrence of paws on $\AA$ land and in central Russia is explained by Dubov as the results of parallel developments on the basis of similar fauna, natural conditions, and socio-economical conditions. This interpretation is most interesting from a theoretical point of view and links up with the tradition of the Marrist school (cf. above) and with ideas common in Anglo-Saxon and some Scandinavian archaeological literature of the 1960s and 1970s (cf. Marr 1934, Malmer 1962, Renfrew 1974).

The Finnish archaeologist C.F. Meinander has treated the clay paw rite in different articles, and in one of them he has placed it side by side with east European imports to Finland, including the Permian metal artefacts (Meinander 1973:148). This must mean that he considers the rite a cultural borrowing from the East. In another paper Meinander writes that the paws demonstrate a close connection between Åland and central Russia. At the same time he argues that the Jaroslavl'-area has priority since there occur other clay objects in the graves, like rings of burnt clay (Meinander 1979:37). The Nestor of the archaeology of $\AA$ land, M. Dreijer, has lately put forward the idea - somewhat in line with Ouvaroff's ideas - that the paw finds in central Russia and on Aland have their roots in ancient religious and magical beliefs in the Mediterranean world. There is no direct connection between the occurrences in the West and those in the East but they have the same origin (Dreijer 1979:99-103).

In a recent review of the archaeological material which can illuminate the contacts between Scandinavia and eastern Europe, I. Jansson also mentions the clay paw rite. He 
rather agrees with Kivikoski's later view of a Western origin but adds that this element becomes well integrated into the local Finnish rite in the Jaroslavl'-Vladimir area. Jansson also hints at the possibility that the paws have been more common in eastern Sweden than is known today. They have been overlooked in the excavations of graves and could have their origin on the mainland (Jansson 1987:782-4).

As we have seen, the discussion of the clay paw rite has concentrated on two aspects. All scholars dealing with the problem have been very interested in the ethnic attribution of the rite, but it has been impossible to reach a broadly accepted conclusion. There are, if we simplify the issue a little, three interpretations: a western origin, an eastern origin, and parallel development. The religious and magical character of the rite has been acknowledged by most participants in the discussion. A totemistic connection is also agreed upon by most scholars, but the argumentation for it is vague. Concerning the zoological identification, there are also three main alternatives: bear, beaver, and bear and beaver. Characteristic of the discussion are the, in practice, strong geographical limita- tions of all the contributions and the insufficient ability of the scholars involved to develop an interpretation which can explain the phenomena in a meaningful way.

It is now necessary to describe the objects under discussion (Fig. 2). Clay paws are oblong objects with a rounded to oval crosssection at one end and a successive broadening at the other. The broad end has an oval or flat oval cross-section and four or five tiny fingers. In a small number of cases the fifth finger is placed in the middle of the object, centrally or laterally. One side of the paw is slightly concave, the other slightly convex. There is considerable variation in design of the details. This is most apparent in the shape of the fingers, the distinction between the palm and the fingers, and the other end of the paw. More than two-thirds of the known specimens have a very distinct shape with a wrist part accounting for half the length of the object, as well as a distinctly set off palm with terminal short fingers (Fig. 2, far left). The majority of the remaining specimens lack the distinctly set off palm. Exceptional is one paw from Åland (Kivikoski 1934: 384 , Abb. 2) which is broader than it is long (Fig. 2, far right). This specimen also has

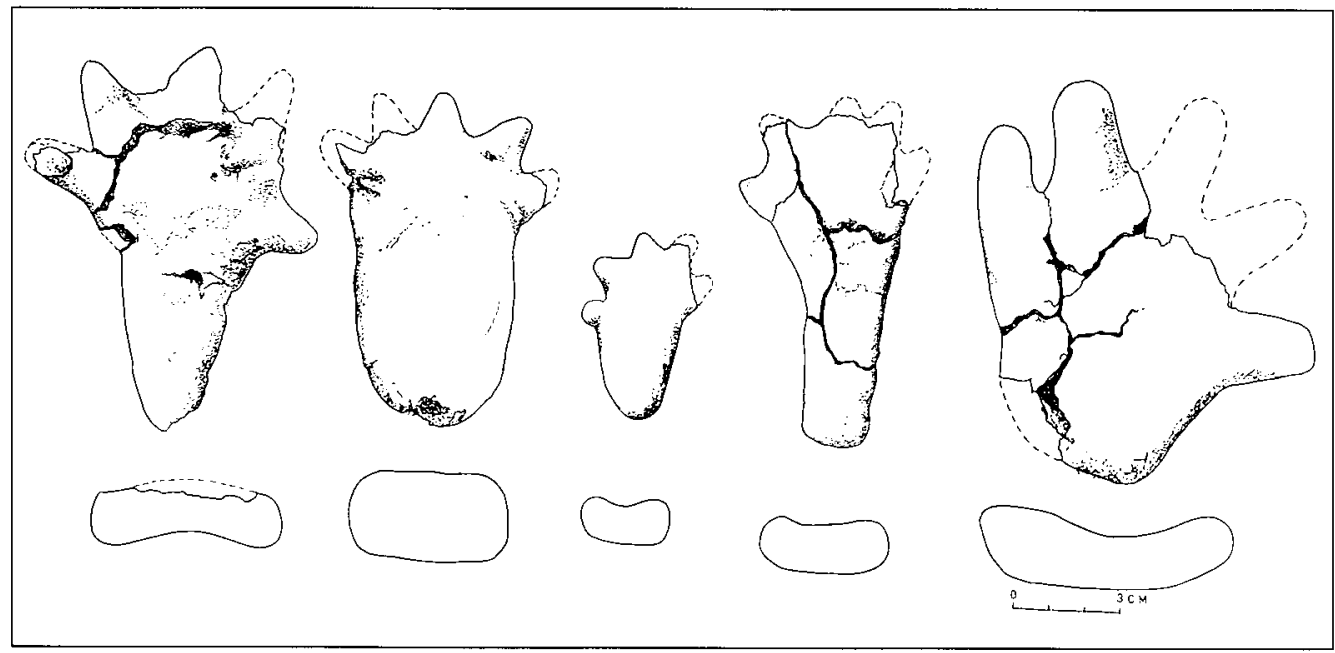

Fig. 2. Examples of clay paws found in graves on the Aland Islands. 
unusually distinct fingers. The length of the objects varies from 5.2 to $11.3 \mathrm{~cm}$. The paws are made of clay with little or no tempering material. The firing of the objects and the insufficient tempering material results in a very brittle product. Consequently, many paws are damaged and incomplete. The character of the clay material is, however, very distinct and thus probably the presence of a paw will be noted in a reasonably professional excavation. Distinct parts are discernible in almost all cases. Jansson's idea that many paw finds have been overlooked is in our opinion not probable (cf. above).

Clay paws are usually found in the layer of charcoal and calcinated bones deposited in the center of the barrow (Fig. 3). Except in a few (6) central Russian graves, only one paw is found in each grave. Probably all paw finds have been made in barrow graves with cremations. The paws are placed close to the urn which often takes a central position in the grave. There are also a small number of inhumation graves noted in Russia where clay paws have been found near the head of the deceased (Ouvaroff 1875:93). The excavation technique used in these cases is, however, poor, and the possibility exists that these inhumation graves have been contaminated with earlier cremation graves in the same barrow. All in all, clay paws have been found in c. 70 graves on $\AA$ land (cf. Kivikoski 1980:34); in more than 156 graves in central Russia of which c. 120 are published (Golubeva 1987:78); in one or two cases in mainland Sweden (Kivikoski 1934:390, Dybeck 1873:55); and in one case in the Ukraine (Blifel'd 1977:187). At present we may state that the earliest appearance of this element of the burial rite is on $\AA$ land.

During a considerable part of prehistory $\AA$ Aland is the eastern outpost of Scandinavian culture. In many respects the population of the Aland Islands throughout prehistory and history has formed an important link with peoples living further east. The very special natural preconditions of the Åland Islands,

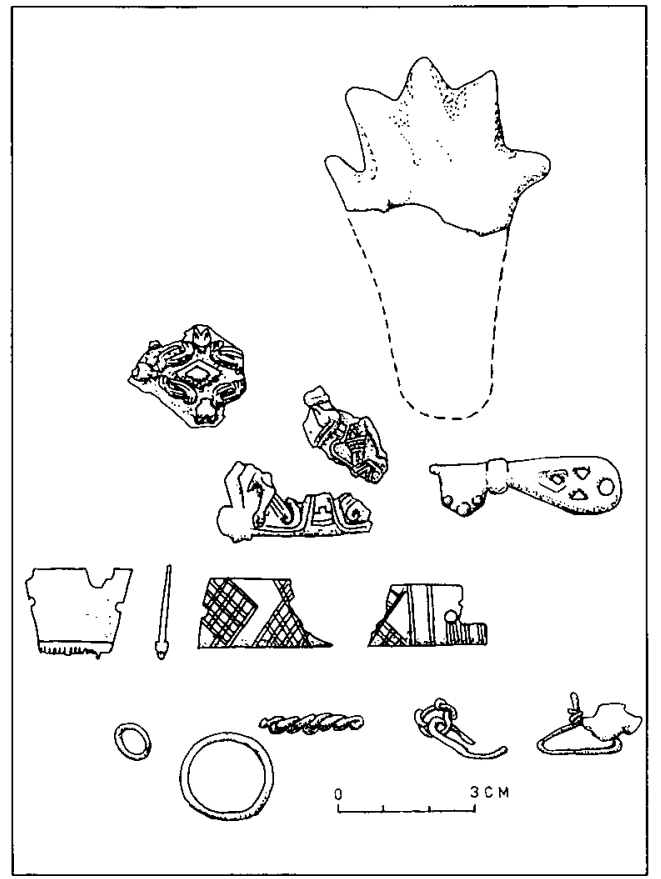

Fig. 3. A ninth-century cremation grave inventory with a clay paw from Knösbuskarna, Svartsmara (Finström).

their geographical and geopolitical position, has led to a specialization which is of great cultural and socio-historical interest.

In the Early Iron age Åland had a permanent human population well adapted to the special natural, mostly marine resources which the archipelago landscape could provide during this time period. Fishing and seal hunting have played important roles (Dreijer 1979:38-40). There have not been any subsistence preconditions for the existence of a dense population. Small groups have been scattered over the archipelago. During the later part of the Early Iron Age conditions change radically. Land elevation in this region, through a combination of effects, provides dramatically increasing areas of new land suitable for animal husbandry (Gluickert 1978). Many of these areas are on clay bottom and emerge as highly productive shore meadows (Palmgren 1961). 


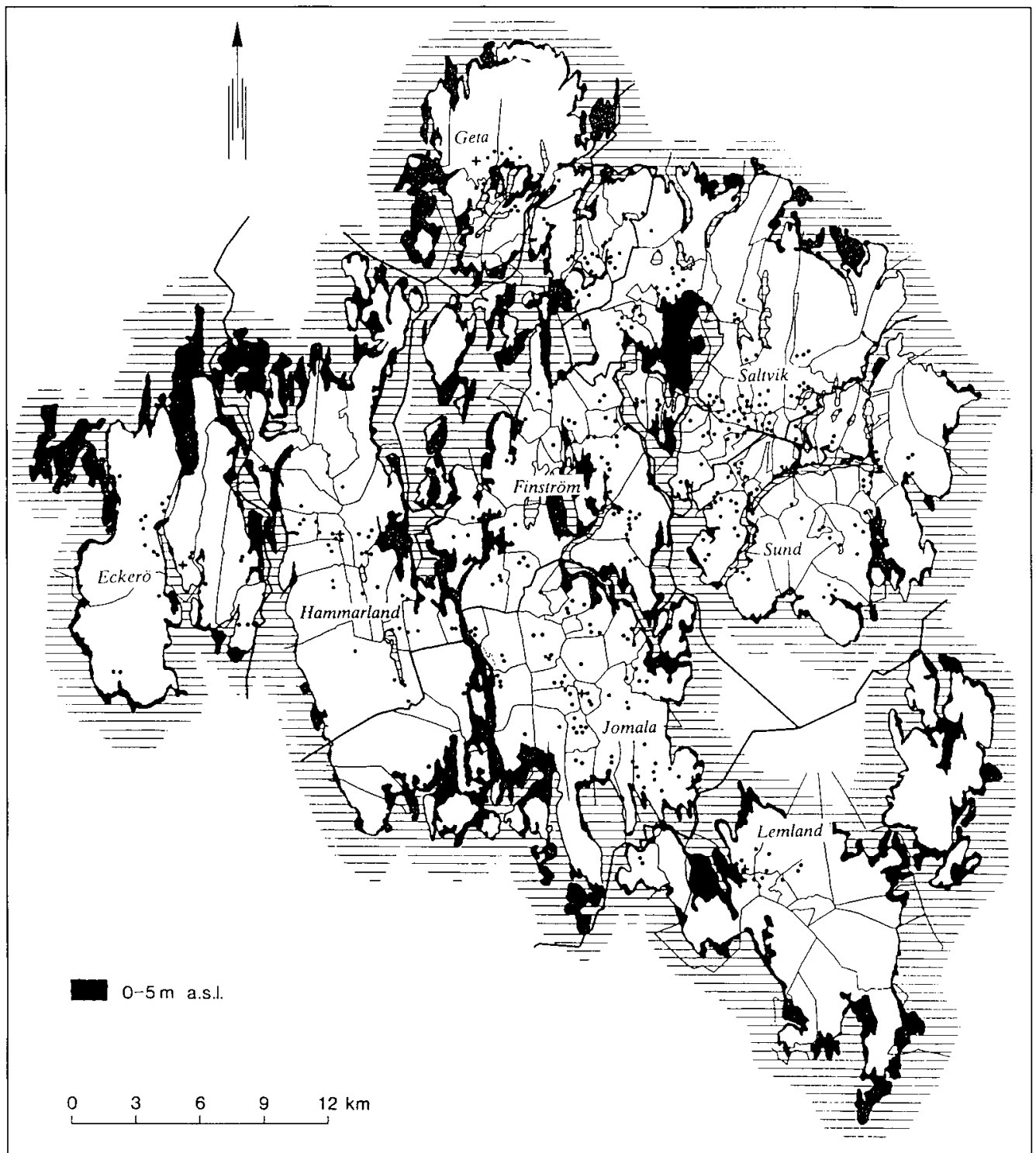

Fig. 4. The Late Iron Age cemeteries of the Alland Islands (after Roeck-Hansen 1991).

With considerable rapidity mainland Åland and Eckerö become quite densely populated (Figs. 4, 5). This rapid population growth cannot be understood as an endogenetic demographic process. Rather, it should mainly be interpreted as a large-scale colonisation process. From where this population originates has not been clarified with certainty. House-types and burial rites are not com- pletely identical to those of eastern middle Sweden known so far. In addition to this part of middle Sweden, a migration from parts of the coastlands of Norrland is possible. The expansion of settlement on Alland is contemporaneous with the time of the late Migration period and the early Vendel Period which several scholars understand as a period of stagnation and in some areas as a certain reg- 
ression in Norrland (Selinge 1977:156). The cemeteries are, however, structurally different from those on Alland. It is most probable that the immigrants came from more than one region.

During the time of only a few generations an, in several respects, distinct agrarian Iron Age culture evolves on Åland, certainly partly on the basis of the autochtonous population and in particular partly on the basis of immigrants. The clay paw is only one element of the specific grave rite which is adopted. The small and dense stone packing in the centre of the barrows is another (Fig. 6). The greater relative height of the barrows is still another. The population on the Aland Islands very rapidly develops these new traits and new combination of traits which obviously, from the very beginning, become widely accepted. Geographical dislocation over considerable distances is in itself a very

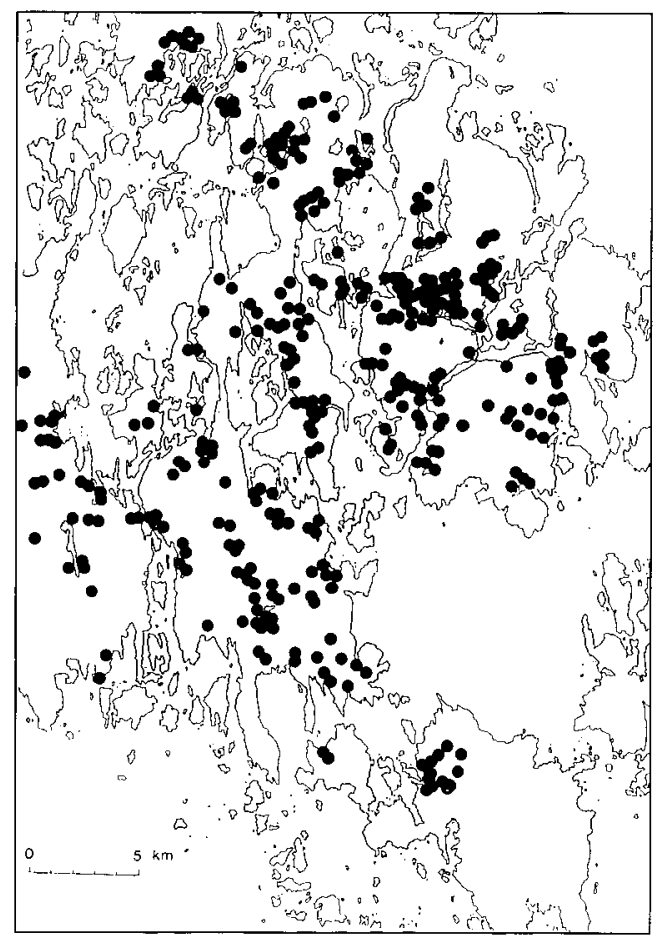

Fig. 5. The Late Iron Agecemeteries of central Aland (coastline 5 m a.s.l.).

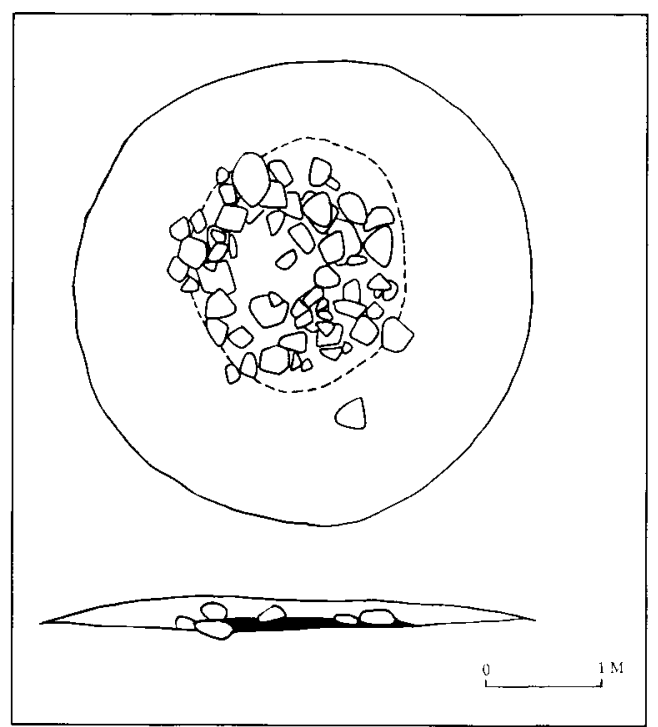

Fig. 6. A barrow with a cremation grave (no. 49) from Larsas Kvarnbacke, Bertby (Saltvik).

strong impulse to social and cultural change (cf. Rouse 1986:173f). It does not mean that some elements are not conservatively maintained. This is an important but often neglected aspect of colonization processes and migrations. It is probably a great mistake to expect identity in cultural patterns between the area of origin and the new land. The process is too rapid. The cemeteries mostly comprise ten or so graves. There are, however, a few cemeteries which are very large (at least 12 have comprised more than 100 graves). One example is the cemetery at Kyrkoby (Jomala), which may have consisted of several hundreds of graves originally (Fig. 7).

Already in the early cremation graves of this "new" population on $\AA$ land we encounter pawlike clay objects among the finds. These pawlike objects made of a special fine clay are often placed in the graves. Of c. 650 excavated graves on $\AA$ land (status 1980) about 70 are furnished with a clay paw (Fig. 8). The paws, as already pointed out, occur in rather variable shapes but must be understood as a distinct type of object. It is, however, of importance here to further specify some 
peculiarities of this element in the grave rite. As mentioned above, this burial custom in Scandinavia is limited to the Aland Islands with only insignificant exceptions. It is indeed our conviction that the exceptions are so few that this general statement cannot be seriously modified. There is an additional find, as already noted, from the northwestern part of the province of Södermanland in eastern middle Sweden (mainland) (Kivikoski 1934:390). This find, with reference to the stamped pottery and the monochrome, mostly reddish-brown opaque beads, can be assigned to the early Vendel Period, i.e. the beginning of the seventh century or slightly later (cf. Arrhenius 1960:74). The other Swedish find is somewhat uncertain since the two

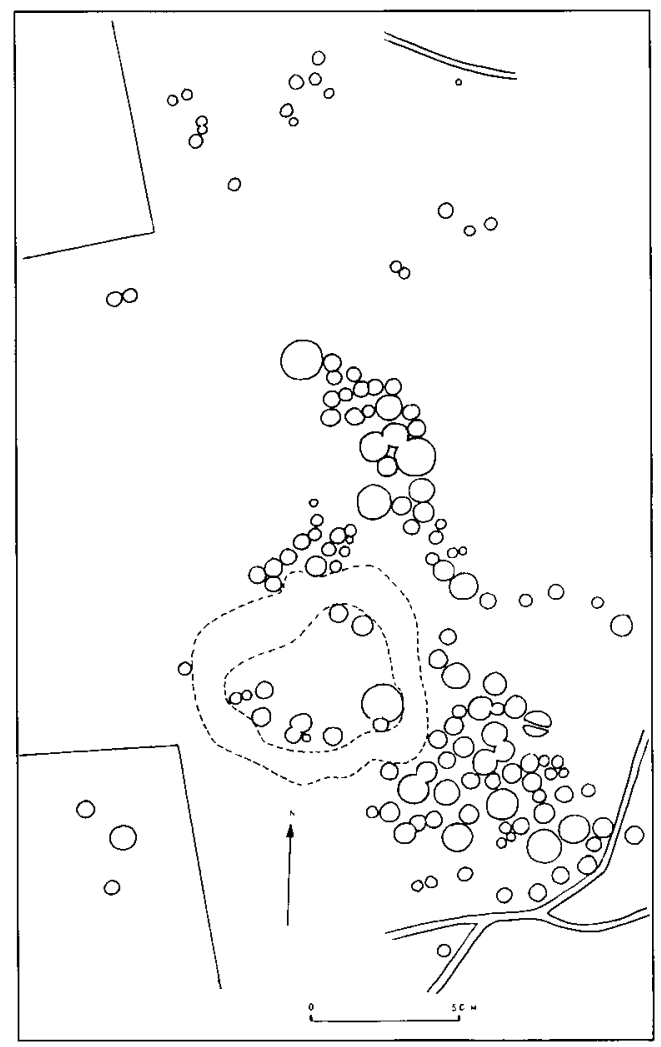

Fig. 7. The cemetery at Kyrkoby (Jomala) is one of the largest on the Aland Islands and it was once even larger: paws recovered are not preserved today, and since, the original publication describes them as made of sandstone (Dybeck 1873:55). The grave was a female cremation grave with a tenth-century oval fibula (Petersen 1928: 67-71). If this find is indeed relevant for our study is uncertain, too, because paw-like objects were found in the grave. Otherwise the use of clay objects of this kind is not known in Scandinavia, and consequently this element of the burial rite must be understood as an innovation of the late Migration Period or early Vendel Period connected with the settling of Aland by largely exogenous population groups. The ideas behind the rite may, however, be considerably older. The use of clay paws on Aland is known already from the seventh century. Four graves can be attributed to this century on the basis of the occurrence of early antler combs with characteristic decoration (ÅLM 358:3, 380:24; FNM 4627:278, 8318:59). Two additional graves could be given a seventh-century date with reference to distinct beads and a fibula find ( $\mathrm{L}$ M 339:11; FNM 4624:17) and four graves, with a certain reservation may also be given the same date ( $\AA$ LM 158:30, 234:11, 397:192, 492:3).

Finds of clay paws have been reported from all parishes of mainland Aland (Fasta Aland) and from Eckerö. It is, however, in this case as in so many other cases the densely populated settlement area of eastern Åland which dominates with regard to the number of finds. Almost $90 \%(88 \%)$ of all graves (here and below, all counts are made from a sample of 61 graves which could be fully documented) with clay paws have been excavated in the four parishes of Finström, Jomala, Saltvik and Sund. Owing to the great internal correspondence, Saltvik and Sund are treated here as one area while Finström and Jomala make up another distinct area. This division into two main areas is also corroborated by the geographical features. The two areas are situated on both sides (opposite sides) of a north-south orientated 
Fig. 8. Partly or completely excavated cemeteries on central Åland. The small symbols mark the excavated cemeteries without paw finds. The large symbols indicate excavated cemeteries with paw finds. A circle round a symbol marks a cemetery with more than ten excavated graves.

bay of the sea called Kornäsfjärden. This division also largely corresponds to the treding boundary known from the late medieval period on Åland between Saltvik treding and the tredings of Finström and Jomala (Voionmaa 1913, Ambrosiani 1948).

The domination of the four parishes is less striking if the number of clay paw graves is related to the number of graves

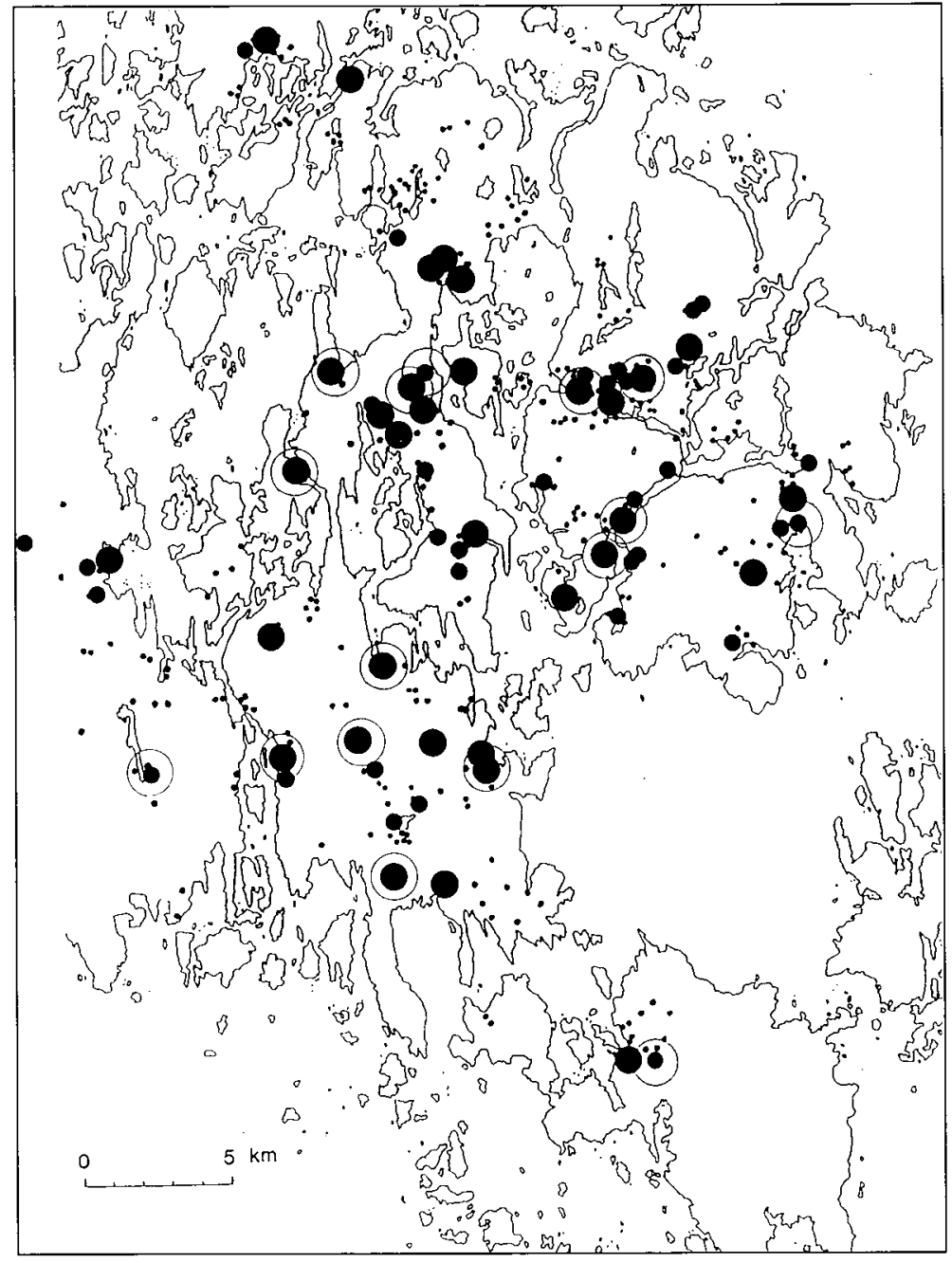
excavated in each parish. A more differentiated picture is obtained. Both Sund and Saltvik have a rather low percentage of clay paw graves (5\% and $7 \%$ respectively), whereas both Geta and Hammarland produce higher values (10\% and $9 \%$ respectively). On Eckerö and in Lemland only one observation has been made in each parish. In the neighbouring parishes of Finström and Jomala the frequency is considerably greater. In Jomala as much as every fifth grave is a clay paw grave, whereas the frequency is a little lower in Finström (15\%).

In order to better understand the occur-

rence of the clay paw graves a study of the frequency of clay paw graves in the individual cemeteries is informative. Only cemeteries with ten or more excavated intact graves (cremations) have been analysed. Of sixteen cemeteries with this number of excavated graves, there were clay paws in twelve. Cemeteries tentatively without paws were found in different parishes. Only in Saltvik did all cemeteries contain graves with clay paws. Eckerö and Geta were, however, not represented in this sample. Usually clay paws occur with a frequency between two and ten 
Fig. 9. Cemeteries on central Åland with a high frequency of paw finds.

percent. Strongly deviating values of representation could only be found in three cemeteries (Fig. 9). At Långängsbacken in Sund there are five graves with clay paws but they make up only 5\% (106 excavated graves). It is notable that the three cemeteries rich in clay paw graves are all found in a restricted part of west central Åland. They all occur in similar locations at narrow passages or at the end of an inlet (vik). In Jomala we can note the cemetery at Sandskiftet in Södersunda (ÅM 124, 136) with $36 \%$, and Lagnes-

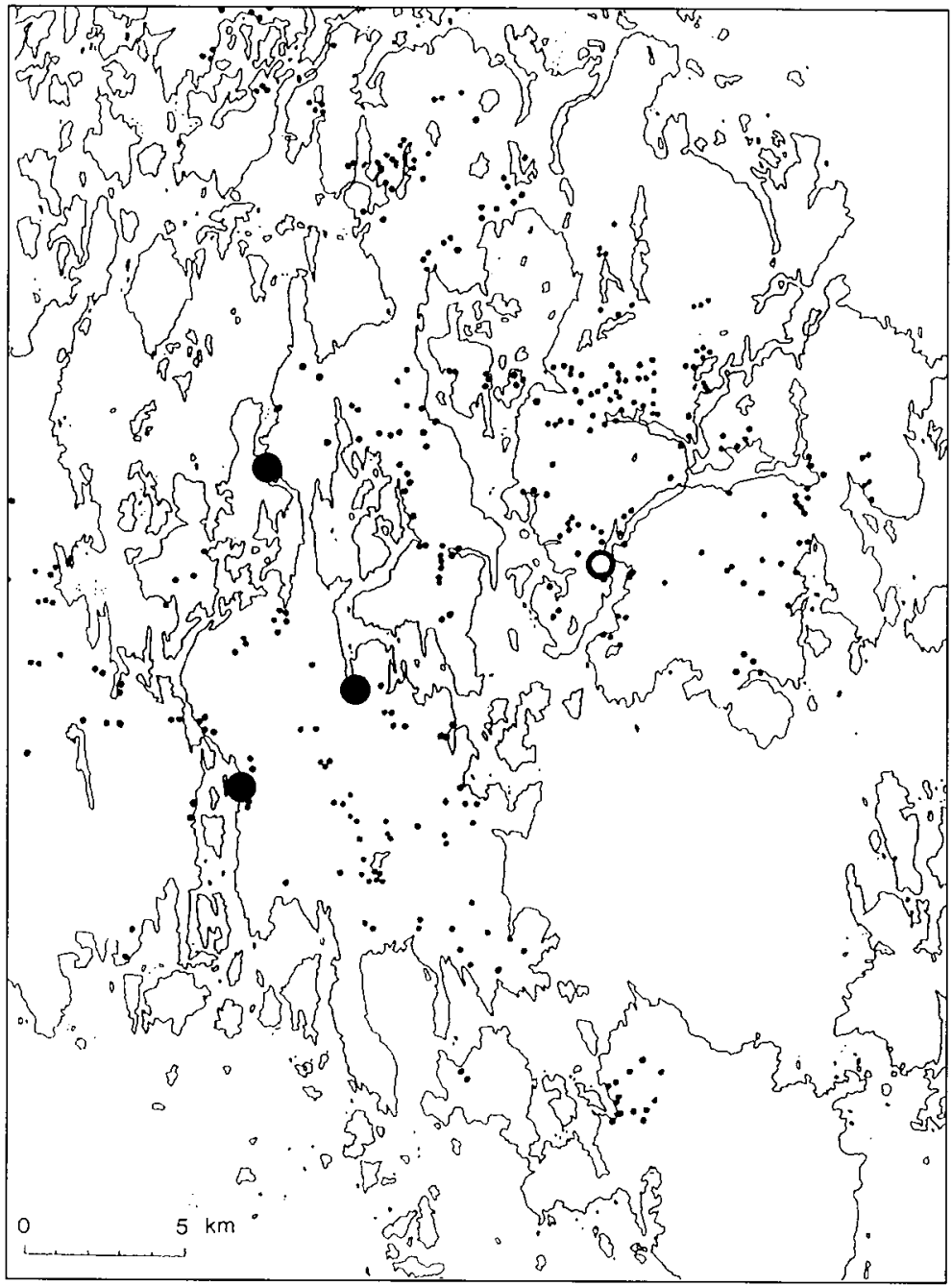
kärrsbacken i Gölby (Dreijer 1959) with $25 \%$. In Finström it is the cemetery Knösbuskarna/Knösbackarna in Svartsmara which can contribute with as much as $44 \%$ clay paw graves (Dreijer 1945). It is thus obvious that the frequency and the distribution of the clay paw rite are markedly different in various parts of $\AA$ land.

If we now consider that we have some idea of the spatial distribution of the clay paw graves, it is necessary to take a closer look at the chronological differentiation of them. Looking at the chronological attribution, we can conclude that there are consider-

able differences. Unquestionable Vendel Period grave finds with clay paws are known from all parishes except Hammarland and Lemland. The geographical distribution of these early graves is, however, uneven since Saltvik and Sund together have more than double the number of Vendel Period finds in comparison with Finström and Jomala, which, when considering both the Vendel Period and the Viking Age, dominate. It is also important here to try to combine this information with the sexual attribution of the graves. Using traditional criteria, above all the 


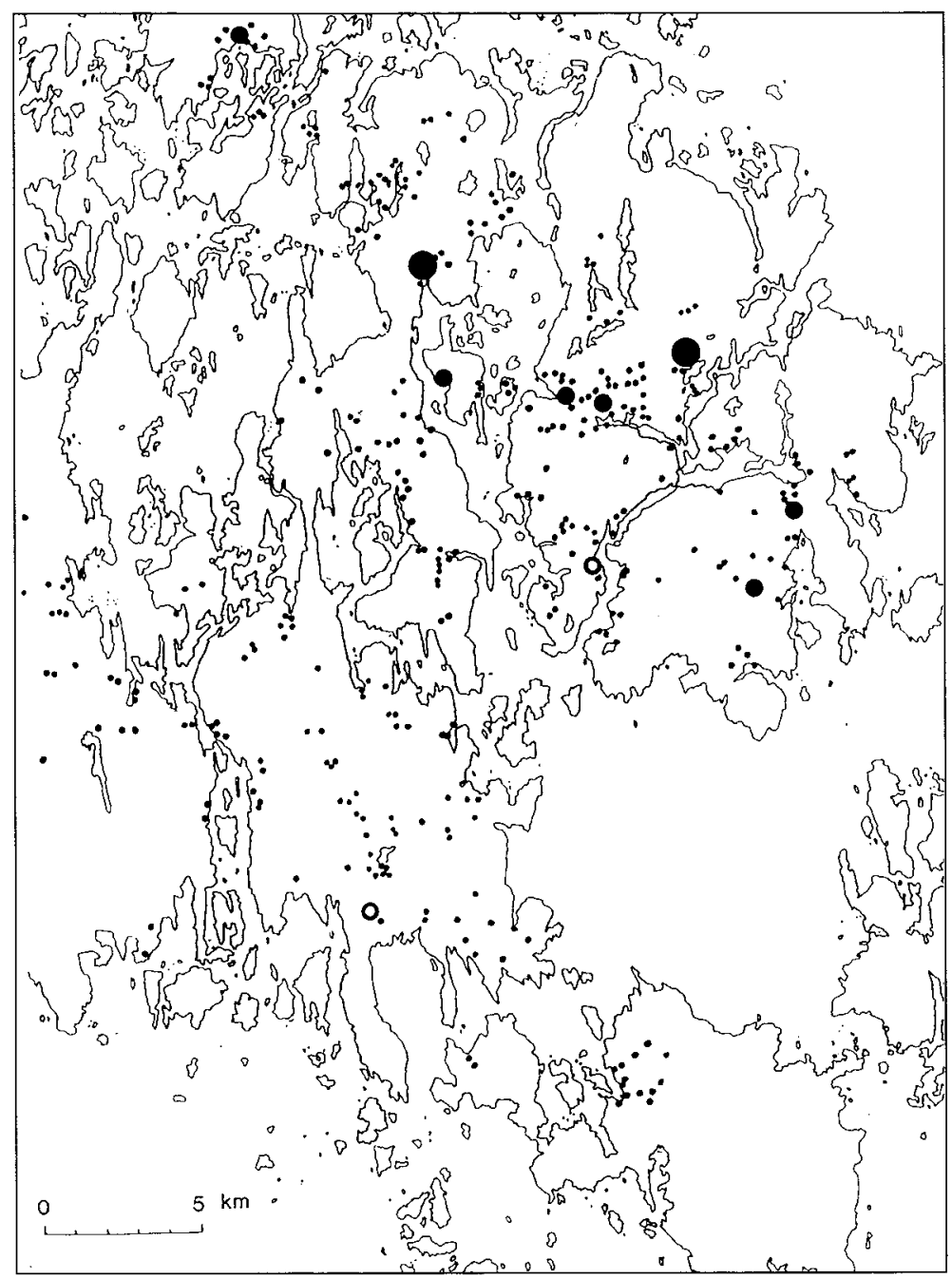

Fig. 10. Seventh-century graves on central Aland with paw finds. Large symbols indicate female graves and small symbols male graves. Open symbols mark graves which cannot be sexed with the methods used here.

restricted to the northeastern part of Åland (Fig. 10). During the Viking Age clay paw graves become more and more unusual in Saltvik and Sund at the same time as their number increases markedly in Finström and Jomala. The latter area now dominates in absolute numbers. The dominance of male graves with paws is still evident in Saltvik and Sund, whereas there is a strong dominance of female clay paw graves in Finström and Jomala during the ninth cen-

numerous beads $(>10)$, brooches and other ornaments, to single out the female graves and belt details and weapons to designate the male graves, it is possible to reach certain tentative conclusions of considerable interest. We now find that among the Vendel Period graves the majority or possibly all graves in Finström and Jomala are women's graves, whereas three quarters of the graves in Saltvik and Sund are male graves (nine of twelve). The remaining three graves could be male graves too. For the early Vendel period we can note that the clay paw graves are almost completely tury (Fig. 11). Only in the tenth century is there a better balance in the sexual attribution of the graves in the latter area (Fig. 12).

It is with reference to this remarkable sexual differentiation between the two areas on each side of the bay that it is easy to associate to some sort of special connection or exchange or complementary relationship. It is then natural to look at other kinds of evidence of exchange between distinct population groups. An important fact is that Finnish grave pottery, which is indicative of close contacts with the population of southwestern 
Fig. 11. Eighth-and ninthcentury graves on central Aland with paw finds. Large symbols indicate female graves and small symbols male graves.

Finland (in a few cases an Estonian provenance cannot be excluded), is equally well represented in the two areas confronted during the Vendel Period and during the earliest part of the Viking Age (Callmer unpublished) (Fig. 13). For the tenth century we can note a sharply rising number of Finnish vessels in Saltvik and Sund and a contemporaneous opposite tendency in Finström and Jomala (Fig. 14).

Our studies of the clay paw burial custom have demonstrated that there are very considerable changes, modi-

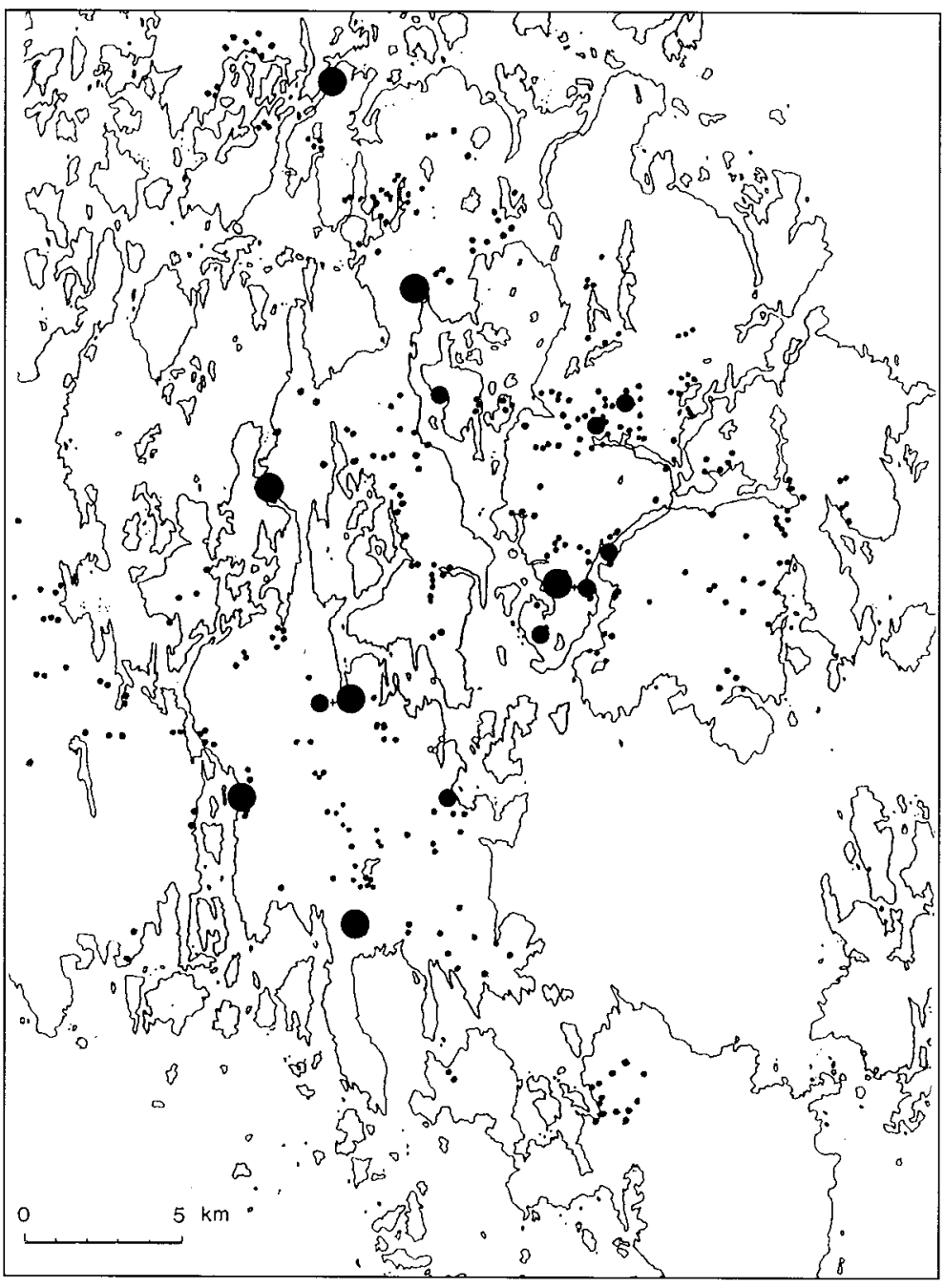
fications, and dislocations involved in it, especially if we compare the Vendel Period and the early Viking Age on one hand, and the later part of the ninth century and the tenth century on the other. The mental templates which are a precondition for the application of the clay paw rite become vague in the later period to the east of Kornäsfjärden in Saltvik and Sund, while at the same time in Jomala and Finström they continue to be strong and the number of graves with this attribute increases. We can also note that there is a different social/sexual connection of the rite in the two areas despite a prima facie strong likeness.

The clay paw rite in the early period shows us that there existed social territorial groups with a wide internal fund of shared ideas comprising quite large areas like Jomala-Finström and Saltvik-Sund.

In order to come closer to possible interpretations of the clay paw rite it is necessary to consider what the paws are supposed to represent and depict. As already pointed out, Kivikoski in her article of 1934 presented some interpretations of the paws by a 


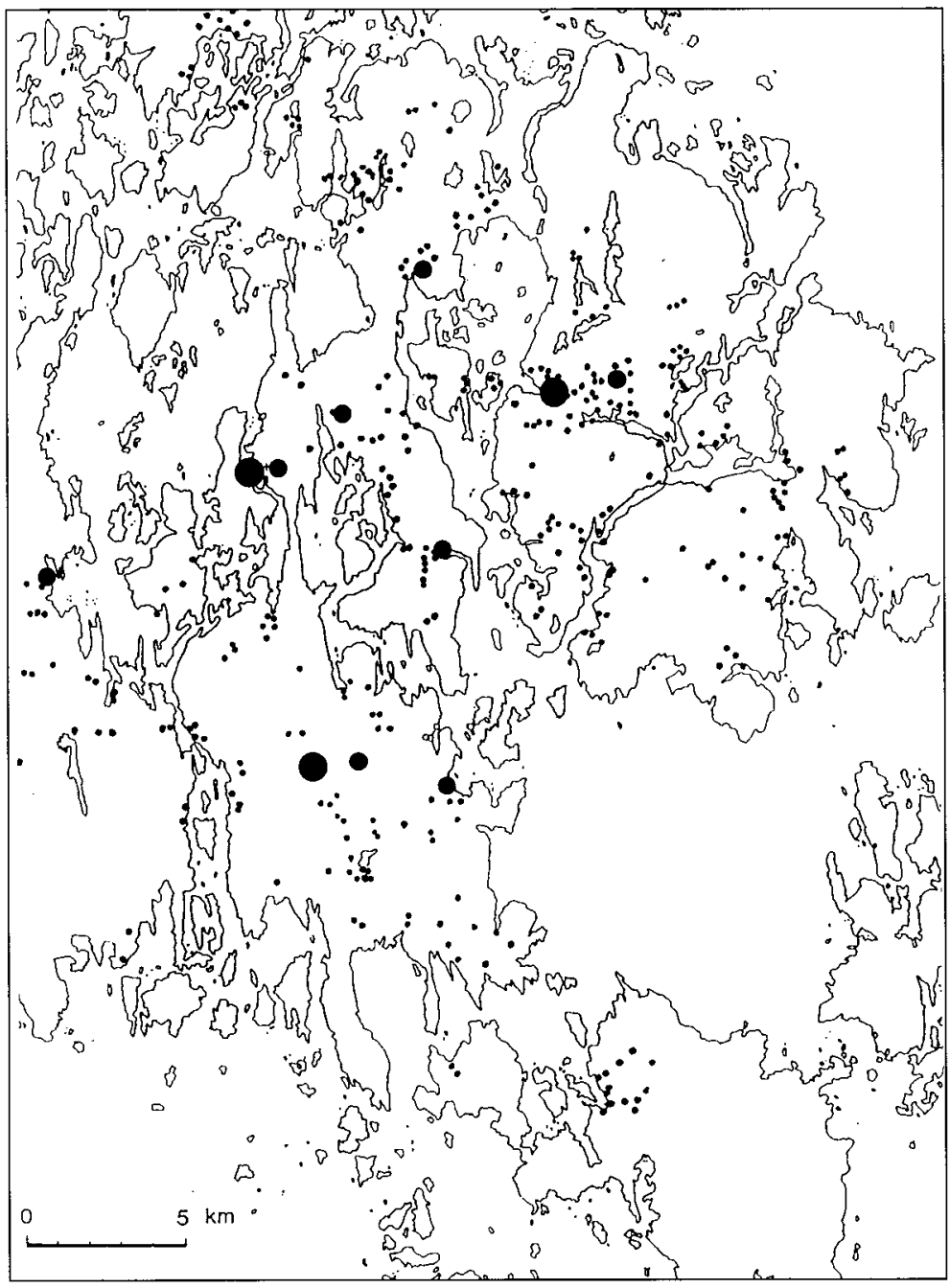

Fig. 12. Tenth-century graves on central Aland with paw finds. Large symbols indicate female graves and small symbol male graves.

tations of human hands which have functioned as symbols of some positive force and which have protected the deceased against danger and injury (1979:101-3). Dreijer, is as already mentioned, of the opinion that these symbols had been borrowed from the Mediterranean world or western Europe. This interpretation must be regarded as less probable because representations of the human hand are very uncommon in the ornamental art of northern Europe during the period of interest, and because the clay paws,

zoologist (Kivikoski 1934:390-1). Bear and beaver were suggested in several cases. In a later systematic examination of new finds from 1934-1965 another zoologist could further confirm this likeness to the two animals mentioned (Kivikoski 1965:30-1). As already stated, the vast majority of the clay paws from Aland have five "fingers" set in a row at one end of the object. Only a few specimens have a spacing of fingers which has a remote likeness to a human hand. It has been mentioned that Dreijer favours an interpretation of the objects as represen- as pointed out, show only a remote likeness to a hand. It can be added that the paw finds with a spacing of the fingers which are closest to that of the human hand are of Viking Age date, and all closely datable finds belong to the tenth century, i.e. the end phase of the clay paw burial custom.

Also the interpretation of these clay paws mainly as representations of beaver paws and possibly to a certain extent as bear paws meets with a number of difficulties. It cannot be considered likely that Åland, after the expansion of settlement at the beginning 
Fig. 13. Ninth-century grave finds of Finnish pottery on central Åland.

of the Vendel Period, has sheltered a bear population. Remote and non-settled areas were not extensive, and the landscape was often cut into tongues by bays which have made battue hunts easy to organize.

The natural landscape of $\AA$ land is not a biotope well suited to the beaver. Also the geological history of Aland makes it unlikely that there could have been a spontaneous colonisation of beaver (Meinander 1979:37). There are few small lakes and brooks today, and the situation was the same in the

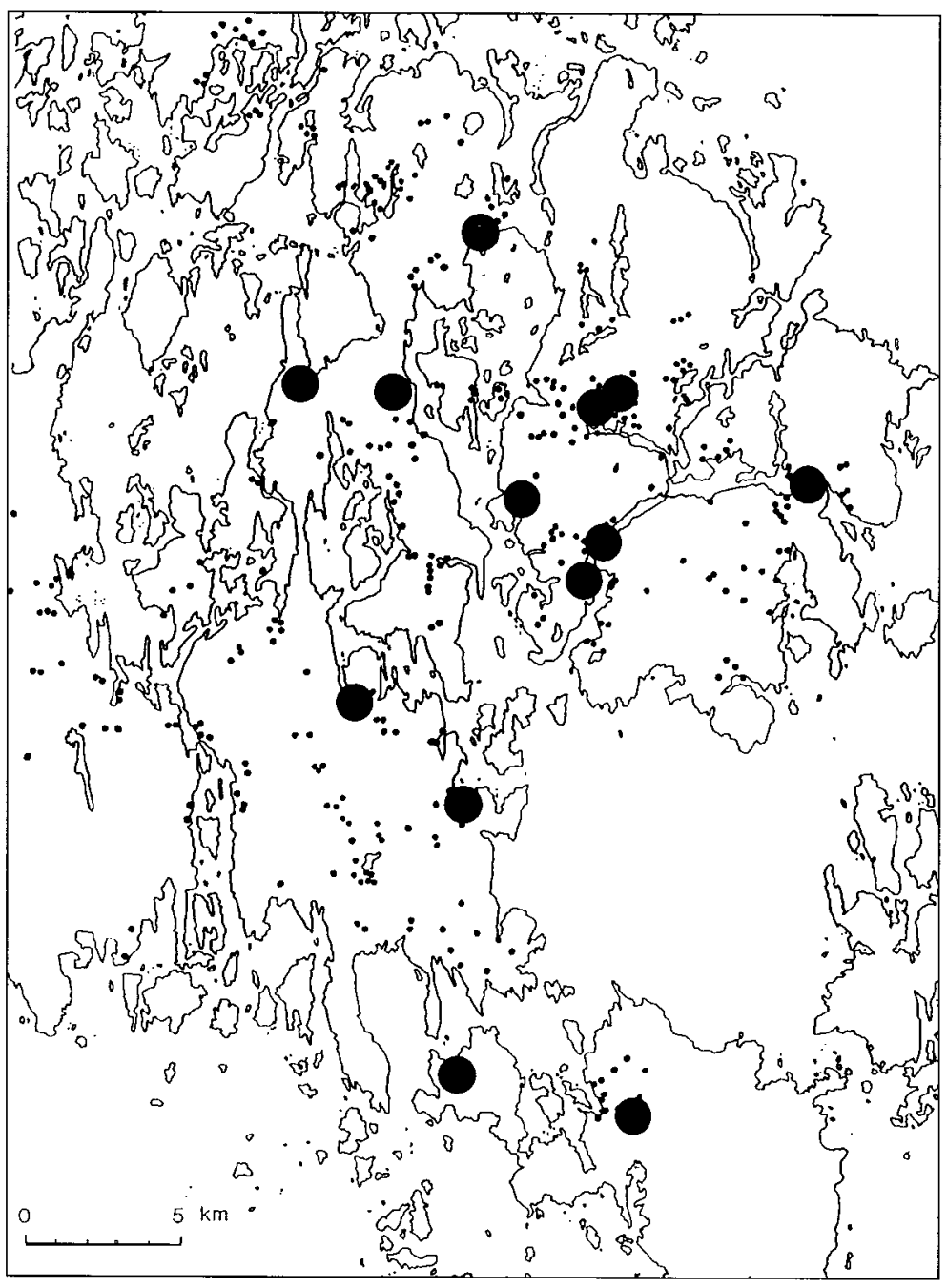
Late Iron Age. However, the find in a

peat bog of an alder trunk gnawed by beaver has demonstrated that the animal lived on Åland (ÅLM). We may, however, conclude that during the Late Iron Age there was certainly no bear hunting on Aland, and with a high degree of probability no large-scale beaver hunting. If bears existed at all on Åland, they must have been extinct already in the Early Iron Age if not earlier. Beaver might have existed only in remote areas, e.g. in the inland parts of Lemland which were uninhabited during the Late Iron Age, and which are rich in swamps. It can be main- tained that beaver cannot have played an important role as a food resource or as a furbearing animal during the Late Iron Age. If the clay paws should be interpreted as representations of beaver and bear paws, they must be connected with ideas rooted in older tradition and myths concerning these animals which have been narrated from generation to generation, or else there was a constant knowledge of the behaviour and appearance of these animals acquired through direct contact with them in an area outside Aland. If the latter alternative was the case, the obser- 


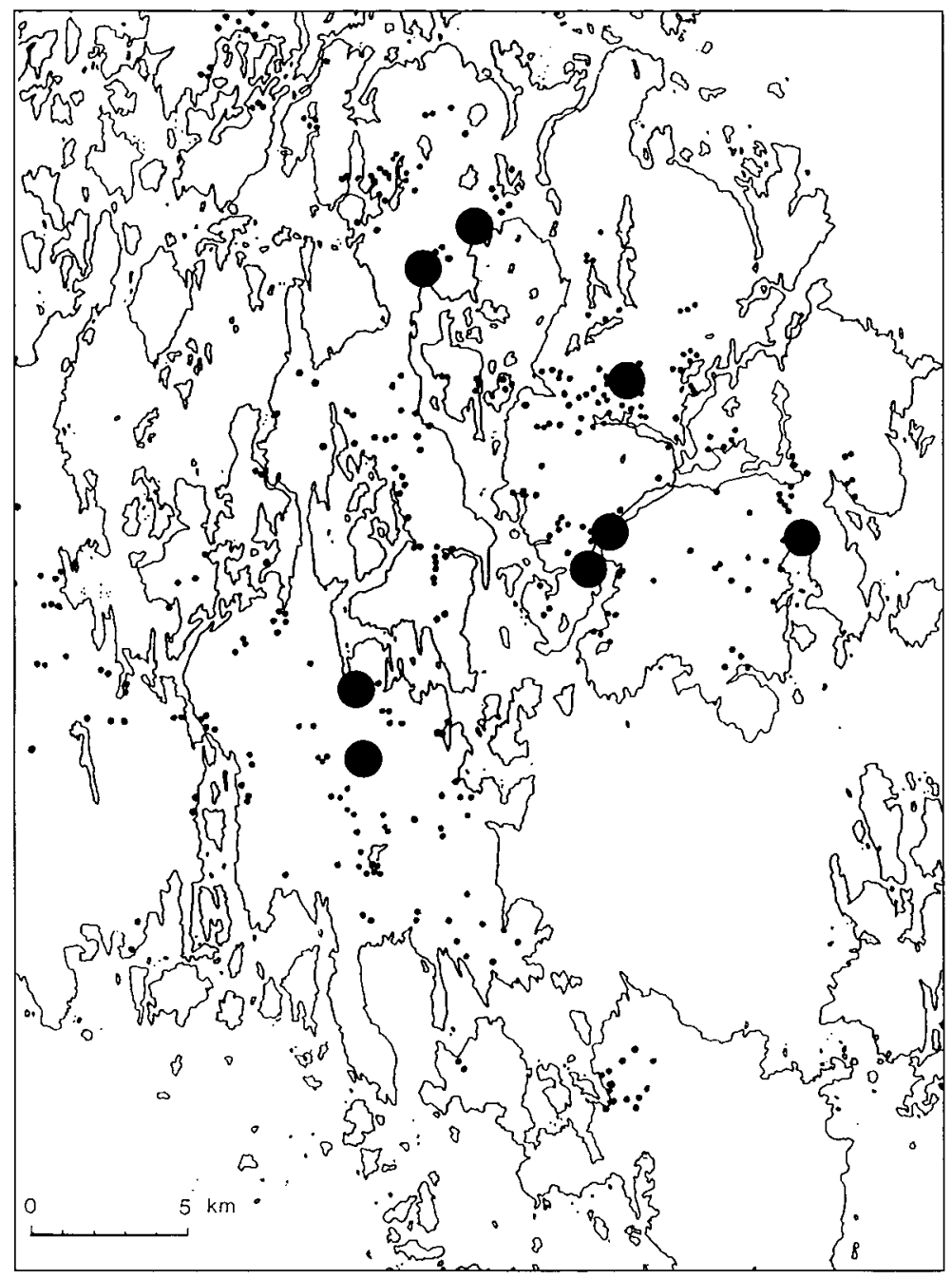

Fig. 14. Tenth-century grave finds of Finnish pottery on central Åland.

taboo names of the bear (the brown one, the honey-eater, etc.). The beaver especially, with its elaborate building activities, has often been empowered with special magical and religious gifts (Skalon 1950:134-59). The importance of these animals as bearers of furs that were of central importance in exchange and trade of fur products in northern Europe in the Late Iron Age must also be emphasized. Bear skins were obviously prestigious items much sought after by local chiefs and "big men" in southern Scandinavia and Gotland and probably also

vations must have been made in connection with the active hunting of these animals and the experiences could not be acquired in another way, for example, through an exchange of furs of these animals. An interpretation of the paws as imitations of beaver and bear paws is also of paramount interest because these animals have a behaviour which in many ways is similar to that of humans. The recognition of the bear as an animal of special magical and religious importance may be traced back to the early history of a groups of the Indo-European peoples, i.a. through the further south in continental Europe where the bear was scarce or extinct (Petré 1980, Iregren 1988). The beaver, along with the sable, marten, ermine and the grey squirrel, was up to the seventeenth century the most important fur-bearing animal in temparate and subarctic Europe (Delort 1978:111-4). Qualitatively the beaver skins were rated very high. In large parts of the Old World beaver gill was also a much sought-after medical substance (Keller 1909:187-8). Below we shall return to the problems concerning the ideas connected with the bear and the beaver. 
The interpretation of these paws as representations of beaver and bear paws necessarily brings forth the assumption that these animals were hunted by a part of the population on the Aland Islands in an area where there were good preconditions for the existence of these animals. From this there also follows another assumption, namely, that this type of hunting must have been quite common already during the earliest stage of the colonization of the Aland Islands by immigrants from the Swedish mainland. Under these circumstances it is not improbable that this tradition of hunting on distant huntinggrounds was also well known before this period. Further, it is important to remember that far from the whole population was associated with the clay paw burial custom. A number of cemeteries probably have no graves with these objects. Rather, we must understand the distribution and the frequency of the deposition of the clay paws as if certain individuals more intensively and more actively than others were connected with the traditions which motivate the custom. These individuals must have been united in a social community characterized i.a. by specific religious and magical ideas. Totemistic beliefs may have been connected with these important furbearing animals.

Where these hunting-grounds could have been situated is not known for certain. If we look at the distribution of settlement along the nearest stretches of the coasts of the Baltic, we can conclude that considerable parts of these coasts had a permanent population with a probable continuity from the Migration Period or even further back in time (Fig. 15). The settlements are in general not situated directly on the coast but a short distance inland, often connected with bays and rivers. Only minor parts of the coasts and the hinterland are wilderness. This holds true for parts of the coast of middle Sweden, the coast of southwestern Finland (Kivikoski 1964: 121) and the Estonian coast from Wierland to the Gulf of Riga (Eesti Esijalugu 1984 t. XV).
Conditions along the Bothnian coasts are slightly different. We find here on the western side during the Migration Period quite a dense population in distinct districts up to Ångermanland (Ramqvist \& Müller-Wille 1987 Abb. 2), whereas the settlement on the eastern side is rather narrowly restricted to minor enclaves in the neighbourhood of Wasa in southern Ostrobothnia (Kivikoski 1964:121). During the Vendel Period the settlement districts along the Norrland coast decline markedly, at least locally, which may imply that some formerly settled land was turned into waste land (cf. above). A similar retrogressive development has been suggested for the settlement area on the eastern side of the Bothnian, resulting in a complete abandonment at the beginning of the Viking Age (Meinander 1977:41-3). It can, however, not be excluded that a certain coastal settlement remains in the area during the Viking Age in southern Ostrobothnia (Baudou 1988).

Very wide stretches of the coastal lands of the Baltic, however, completely lack evidence of a permanent settlement in the Migration and Vendel Periods. From the region of Hangö, the northern coast of the Gulf of Finland completely lacks visible archaeological remains from this period (Kivikoski 1964:121). The stray finds are restricted to some ten oval strike-a-light stones, most of which probably belong to the Roman Iron Age and the Migration Period (Kivikoski 1964:145, fig. 137). This condition is not only characteristic of the coast itself; also land up to a distance of c. $50 \mathrm{~km}$ from the coast is obviously waste land. The lake district even further inland is also almost completely devoid of finds. The southern side of the Gulf of Finland also lacks evidence for a permanent settlement during the Late Iron Age up to the eleventh century from the estuary of the Neva to Wierland. Only one grave find of Estonian type is known from the western part of the plateau of Ingermanland (Spicyn 1896:35). In addi- 


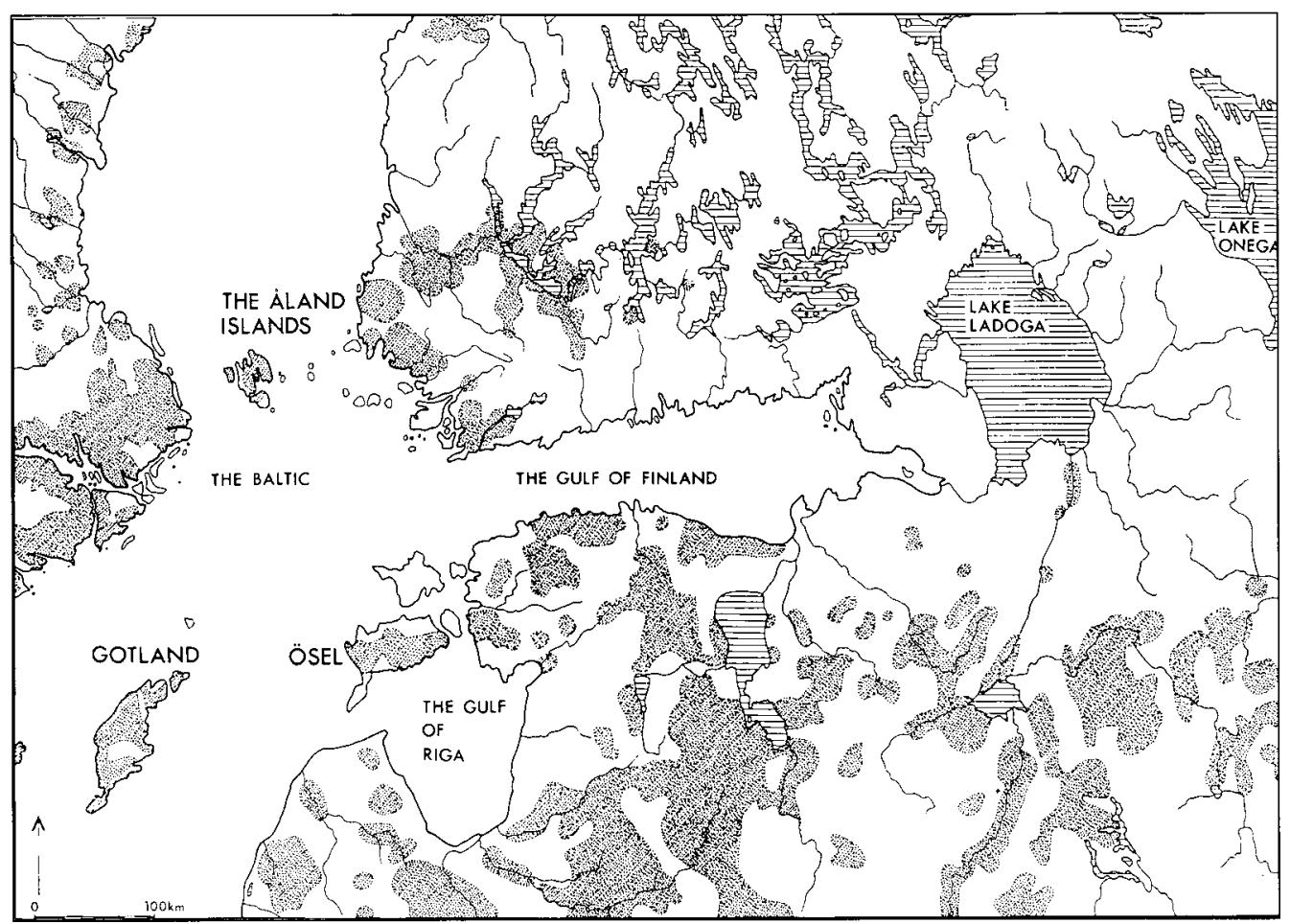

Fig. 15. The permanently settled regions bordering on the Gulf of Finland (third quarter of the first millennium).

tion, a few localities with cremations under flat stone packings are known from the inland. They are, however, few (only three) and lack datable finds, which makes it possible that they may be both older and younger than our period of interest (Sedov 1953:203-4). The same general impression of large areas of waste land also holds true for areas to the east of the Gulf of Finland in the Ladoga region. The coasts of Lake Ladoga during the Vendel Period have not left any observable traces of settlement. Only at c. A.D. 800 , or possibly the very end of the eighth century, do we encounter graves on the northwestern coast of Ladoga and on the Carelian Isthmus (Kivikoski 1944). To the south of Lake Ladoga clear indications of permanent settlement do not reach further down the Volchov than the neighbourhood of Staraja Ladoga (Sedov 1970:9). This may mean that the possibility of a certain exploitation of this region by a population which is invisible in the current archaeological record should not be altogether excluded. Nazarenko, on the basis of his studies of the tenth-century and later grave finds from the area to the southeast of Ladoga, has suggested that these graves are connected retrospectively to a Finnish population practising a burial rite with graves without more substantial markers above ground (cremations in the west and inhumations in the east) (Nazarenko 1982: 144). This idea is, however, altogether hypothetical and as yet there is no substantial evidence at all for this population. If a population existed, it must have been rather small because, after all, quite a lot of fieldwork has been done and numerous Stone Age and Bronze Age settlements are known in the area. Further we may assume that the hypothetical Late Iron Age population at least partly frequented sites similar to those of the 
earlier population in the landscape. We find substantial albeit few traces of a population further east in the basin of Lake Onega, at Beloe Ozero, on the upper Suda River, along the Seksna River, at the lakes Laca and Vože, and at the Suchona River (Makarov 1986:64). The datings of this archaeological material lie mainly in the middle of the first millennium A.D. The possible presence of groups of Saami population should not be excluded (cf. Vuorela 1944:50). There is, however, no positive tangible evidence for it yet.

If we again turn west, we may assume that inner parts of Nyland have composed a part of an erä area system for southern Tavastland; it was not a large part of the enormous area to the north of the Gulf of Finland. It is indeed not unlikely that the north Estonian population had traditional hunting-grounds to the north of the Gulf and in the western part of Ingermanland. Also, if this was so, it is not likely that these distant hunting grounds comprised a large part of this wide, sparsely populated area or perhaps waste land. The enormous expanses of taiga bordering on parts of the coast of the Gulf of Finland and on the Ladoga were an easily accessible resource area for products of the northern coniferous forests which lay open for the population of the $\AA$ land Islands. With their probably excellent light and small ships they could reach central parts of this waste land in a few days. With reference to the sixth-century finds from Tytterskär (Tyttersaari) and Riekkala Island in Lake Ladoga, we have reason to believe that the route was already known during the Migration Period (Kivikoski 1939; see also Meinander 1985). It is then indeed possible that the Alanders - in terms of primitive travel - had easy access to closely situated and wide hunting-grounds where specialized fur trapping and bear hunting could be successfully pursued.

The route eastwards had a long tradition as a communication between the Finno-Ugric peoples from western Siberia to Finland. This route was certainly in use in the seventh and eighth centuries when i.a. so-called Permian (or Nevolino) belts in certain numbers reached Finland from the Volga Finnish area (Fig. 16). Probably it was not a route frequented by the same agents of trade all the way from the east to the west or vice versa. Rather, it comprised a number of interconnected links. As an indication of this we can note the diverse gender connections of the Permian belts in Finland and in the Volga Finnish area. In the east they were connected with female dress, whereas in the west they appear as distinct male attributes of high status.

In the study of the clay paw graves of the Alland Islands discussed here, it has become more and more urgently felt that the remains of the human individuals accompanied by clay paws should be determined by osteologists with respect to age and sex. It is also important that the animal bones in the cremations are studied so that the composition of the sacrified species is clarified. A comparative investigation of the osteological material can give us a better basis for the social position of the deceased. The important questions concern sex, age group, relative material wealth and social position. This necessary complement to the investigation should be undertaken as soon as possible. As pointed out earlier, it has been shown with traditional archaeological methods that probably both men and women were given clay paws as part of their grave-goods. There are also great differences in the number of grave-goods in each grave and the quality of the items. The question of the sex of the deceased person is, as we have seen, of great importance to our understanding of the early stages of the custom of depositing clay paws in the graves. We have already seen that the clay paw graves of western Aland in the Vendel Period and early Viking Age are female graves whereas the graves of eastern Aland are male graves. This important observation gives unique insight into the principles for the division of a social microcosm with a dichotomy for which there are many examples 
Fig. 16. The traditional exchange routes of the Finno-Ugric peoples of northern Europe exemplified by the distribution of the so-called Permian (Nevolino) belts.

in social anthropological studies (cf. Jensen 1966, Watson 1972). The discussion can perhaps be given concrete form if we suggest that the observations made can

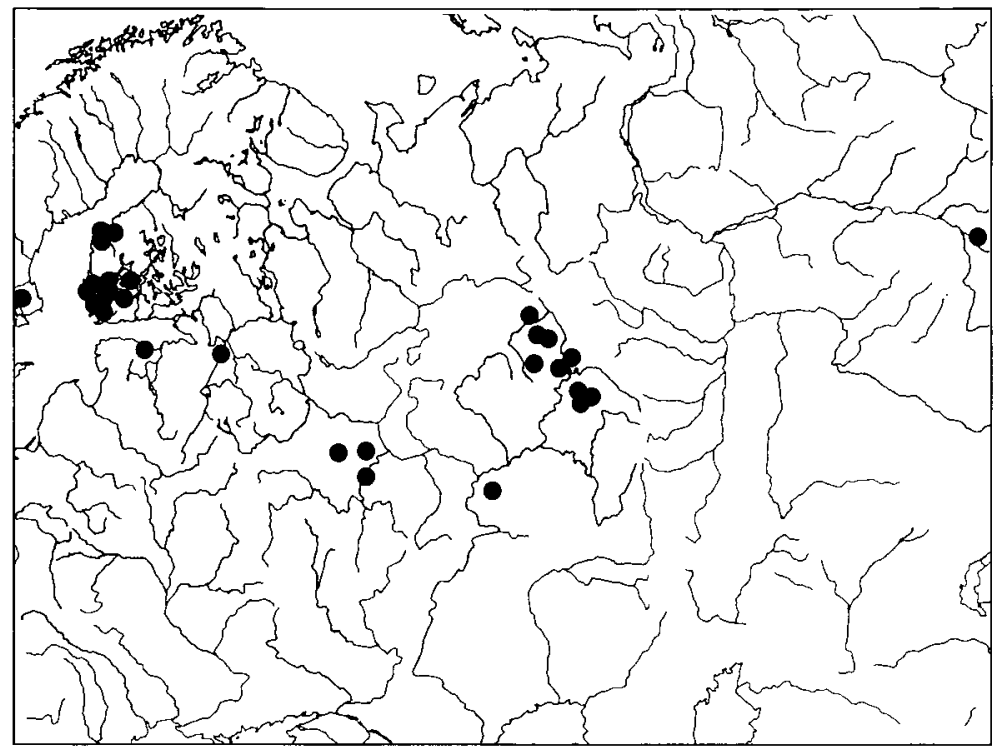
reflect the interrelationship of at least two different exogamous groups. It is close at reach to interpret the paws as totemistic symbols. The graves of the late ninth and the tenth centuries in this set of interpretations show us social changes of considerable extent and the ultimate dissolution of a c. 350 year old system of norms.

In conclusion we may suggest that the clay paw burial rite is connected with a social group on Aland which has great interest in hunting for furs and which undertakes hunting-expeditions to the east. These families have a special institutionalized mythological and religious relationship with the animal(s) hunted. This social group resides in one part of $\AA$ land, and the custom of burials with paws is spread through marriage (exogamy) to another or several distinct parts of the island territory. Whether matrilocality or patrilocality prevails is uncertain, but perhaps the first alternative is most probable and the home area from the late eighth century is then consequently Finström-Jomala. This might be indicated by the strong continuity in this part of $\AA$ land. In the latest phase social contacts of the population of Saltvik/Sund are increasingly directed toward southwestern Finland, including marriages, and the

relationship between Finström/Jomala and Saltvik/Sund loses its exclusive complementary character. Discussions of this kind are not easily brought to a level where we can say that such and such is actually proven. In the case of the clay paw graves of $\AA$ land we cannot go much further. The clay paw burial rite, however, offers additional possibilities to study at close range social and cultural transformations of very great general interest and which strongly indicate that the general ideas behind the interpretation of the Allandic material are not far from what they once were. These possibilities are connected with the additional occurrence of the clay paw rite in central Russia, as stated in the introduction.

It is possible to follow the changes in the grave ritual in connection with a very complicated emigration of population groups from Alland to the Upper Volga. Probably already during the later part of the Vendel Period an area corresponding roughly to the present Jaroslavl' district (Jaroslavskaja oblast) was brought into contact with exchange systems based in the Baltic region. At that time this area in central Russia was inhabited by a Finnish population, a tribe 
Fig. 17. Settlement incentral Russia in the last quarter of the first millennium before the Slavic colonisation. Merians lived in the central and eastern parts. A closely related group, the Muroma, is encountered on the lower Oka River: Late D jakovo settlements existed on the Moskva River and on the Volga from the mouth of the Nerl' to c. $100 \mathrm{~km}$ further upstream. Westfinnish groups lived northwest of the Volga.

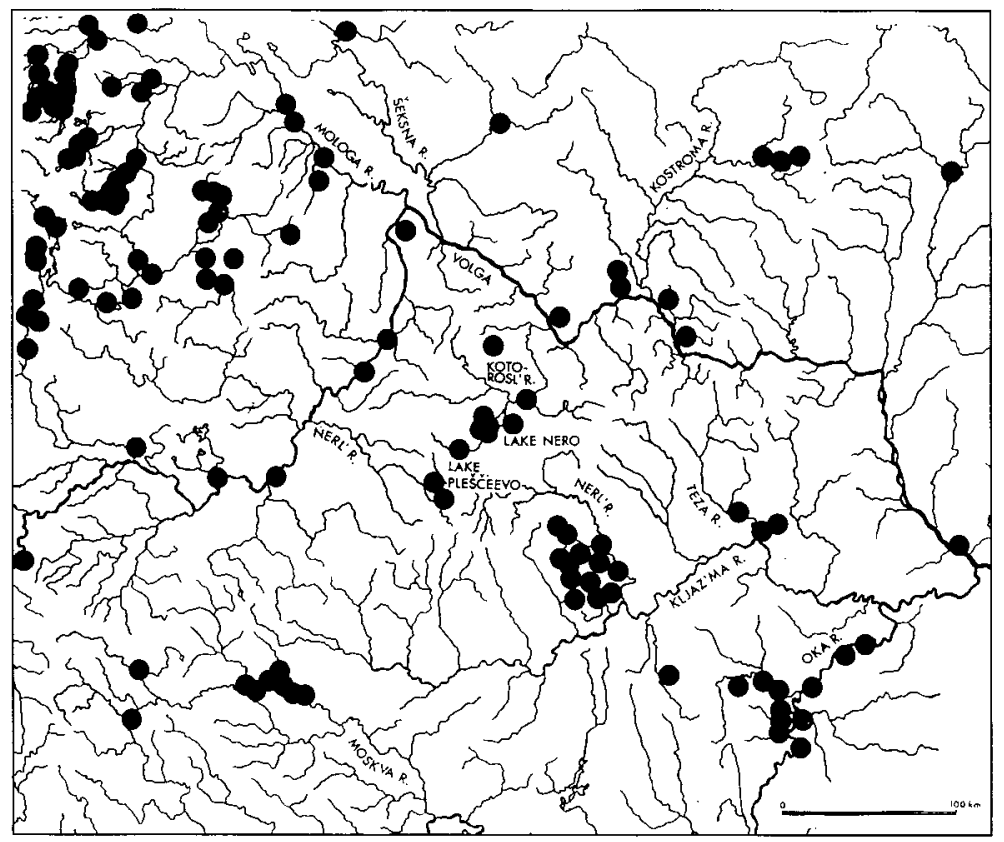

called the Merians (Gorjunova 1961) (Fig. 17). As a distinct ethnic group the Merians existed at least already in the fourth to fifth centuries A.D. since they are mentioned under the name merens by the Gothic historian Jordanes.

A number of imports from the Baltic region which date from the eighth century, most of them found at the central settlement at Gorodisce on the Sara situated not far south from Lake Nero, provide us with evidence of these contacts (Leont'ev 1981: 141f). Corresponding imports, though in small numbers, have been found on $\AA$ land and in eastern middle Sweden (Callmer in prep.). It is probable that groups of traders and possibly also of hunters penetrate this area more and more regularly and more and more completely during the ninth century. Visits of Scandinavians to Merian settlements and the wilderness of this area are probably regular and integrated into a social contact system. The Ålanders had much experience of this type of contact as a result of their close relations with the Finns of western Fin- land. The settlement at Gorodisce on the Sara plays an important role and is obviously a local centre for the Merian population around and to the south of Lake Nero.

During the course of the ninth century several regions in European Russia have archaeological evidence of Scandinavian presence and close links with the trade in the Baltic region. Characteristic is the concentration of these phenomena to small, welldefined areas, often of key significance in the region. Besides the region of central Russia dealt with here, we can distinguish the Staraja Ladoga-Novgorod area, the Pskov area, the Upper Düna and Upper Dniepr areas, and the Kiev area. The highly variable character of some of these areas suggests a heterogenous structure, possibly reflected in the statements of several Arabic writers concerning at least three formations of the Rus' in Russia.

During the second half of the ninth century conditions in this area on the Volga change dramatically. Within a radius of $c$. ten kilometers around the mouth of the Kotorosl' 


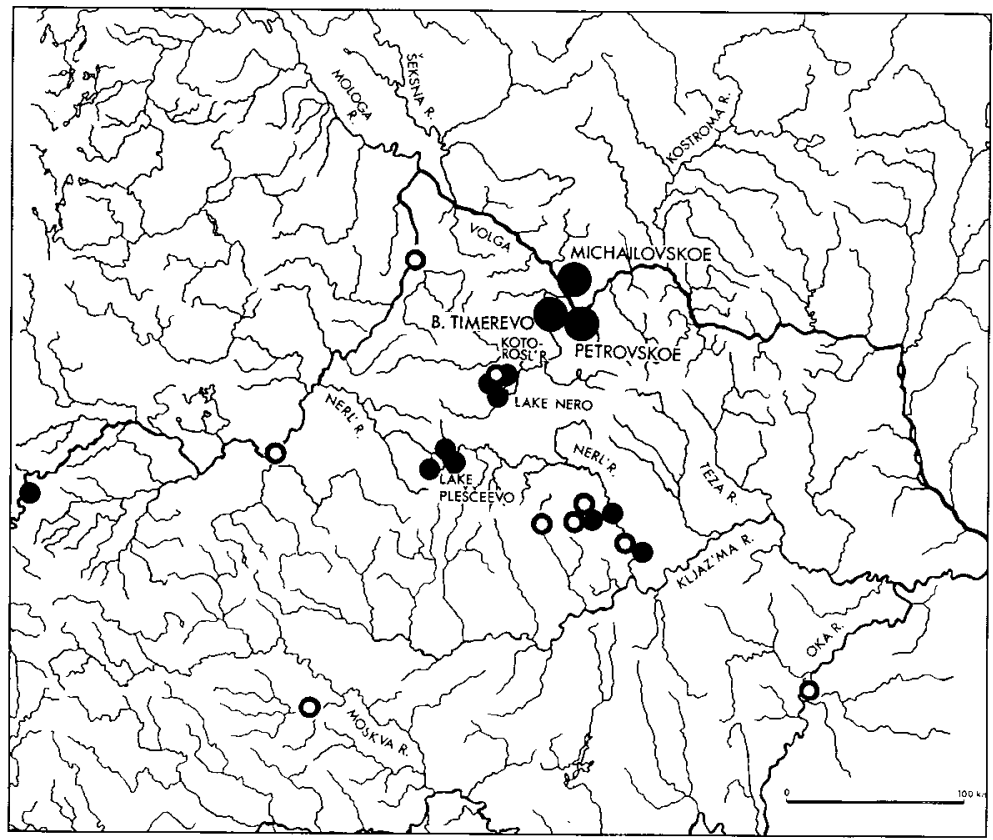

Fig. 18. Indications of Scandinavian presence and contacts with Scandinavians in central Russia (ninth and tenth centuries). The large symbols indicate the three settlements near Jaroslavl'. The small symbols mark other, probably secondary cemeteries with paw finds. The open symbols indicate other find localities with Scandinavian artefacts and graves.

River into the Volga, three settlements with a completely or partly exogenous population are established at the present villages of Michailovskoe, Petrovskoe, and Bol'soe Timerevo (Fig. 18). All three settlements are situated in a characteristic way, i.e. drawn somewhat back from the Volga. This seems to be a common feature for settlements along major parts of the upper and middle reaches of the Volga up to the end of the tenth century. The river banks were not settled, as we might think, for security reasons. In the case of Timerevo it has been possible to demonstrate directly (Dubov 1979:117) and in the two other cases it is likely that the settlements begin on a rather small scale but rapidly grow and develop into very large settlements for the period, especially Timerevo and Petrovskoe (Dubov 1982:143, Fechner 1963: 20). At Timerevo the settlement in the middle of the tenth century is almost eight hectares large. This is a spatial extension which shows us with full clarity that the settlement is not an agrarian settlement of the ordinary type known from Aland and eastern middle Sweden. Above it was noted that there is a small number of very large cemeteries on Aland, too, which may have been connected with very large settlements.

However there are local Merian settlements of a considerable extension on the lakes Nero and Plešceevo (Dubov 1982:98, Leont'ev \& Sidorov \& Islanova 1986:6-7). The character of these Merian settlements is not known closely, and at a fairly early stage they may have comprised exogenous components of population (cf. below). Timerevo is the only settlement which has been subject to partial excavation. The find material recovered in connection with the excavations suggests a population composed of Merians, Scandinavians, and possibly at a later state Ceremissians or even more probably Udmurtians (Dubov 1982:46, Mal'm 1963, Smirnova 1987, Fechner \& Nedosivina 1987). The material is rather rich and also indicates close contacts with Volgabulgaria (Mal'm 1963:49). All three settlements are connected with large cemeteries. At Timerevo and Petrovskoe there existed necropols 
originally comprising more than a thousand graves. Originally the cemetery at Michailovskoe may have included a considerably higher number of barrows than the c. 400 registered in the ninteenth century (Stankeviç 1941:60) (Fig. 19).

The basic grave rite of the cemeteries at Timerevo, Michailovskoe, and Petrovskoe during the ninth and tenth centuries is almost without exception cremation (Fig. 20). Only very few contemporaneous inhumation graves are known; among these we may, however, note chamber graves (Fechner \& Janina 1979). Since we only find clay paws in cremation graves in the three cemeteries the inhumation graves shall not be discussed further in this connection. The grave ritual of the cremation graves and the external appearance of the graves in many respects have traits similar to those we find in contemporaneous east Scandinavian cremation graves (Fig. 21). The occurrence and the layout of the stone constructions is, however, sometimes different already in the early graves in the Jaroslavl' area (Fechner 1963A, Dubov 1982: 140-1). Details in the deposition of the cremations are also sometimes different, and already at an early stage we can discern a grave ritual characteristic of the communities on the Volga exclusively. The development of this grave ritual may probably be interpreted as a synthetic cultural process of the same kind encountered on Alland during the late Migration Period and the early Vendel Period. One or several human social groups in a new geographical area at a considerable distance from the old home range develop new social and cultural norms or modify their earlier cultural pattern. It is most remarkable that already among the finds in the earliest cremations we find clay paws. At Timerevo we find paws in no less than $18 \%$ (46) of all cremation graves. The percentage of clay paws is slightly less at Petrovskoe $(15 \%, 9$ graves) and at Michailovskoe (12\%, 13 graves).

In the graves of the three cemeteries we also encounter rings of clay (Fig. 22). They are
2-3 cm thick and have a diameter of c. 13-15 $\mathrm{cm}$. These rings, like the paws, are deposited on the cremation layer. In a number of cases these clay objects occur in the same grave. At Timerevo it does not happen often that rings are found without paws (in four of 12 occurrences of rings). On the other hand, it is rather uncommon that rings are combined with paws at Petrovskoe. Conditions at Michailovskoe are similar to those at Timerevo and only three of 12 finds of rings are not combined with paws. A substantial difference can also be observed in the relationship between ring finds and paw finds in the three cemeteries. Among the graves at Timerevo which are furnished with paws or rings or both, there are only 12 finds of rings (24\%). The corresponding figure for Petrovskoe is 8 finds of rings $(53 \%)$ and for Michailovskoe 12 finds of rings (75\%).

Although the finds from Petrovskoe are rather few, we can assert that in a significant way the material reflects differences with regard to the grave ritual between Timerevo on the one hand, and Petrovskoe and $\mathrm{Mi}$ chailovskoe on the other. In contrast to the material from the Alland Islands, the osteological material from the majority of the excavated graves in the three cemeteries has been examined and determined by a competent osteologist (Andreeva 1963:92f). These results are an important complement to the observations of differences between the cemeteries, although a certain reservation is necessary when using determined cremations as an archaeological source material (cf. Iregren 1977), this material is so large that the main tendencies should be viewed as significant. At Timerevo the paw graves are male, female, as well as juvenile graves. There are, however, more male than female and juvenile graves (14). It is not unlikely that the female graves are more numerous than the 11 clearly discernible examples (there are a number of male and female graves, female and juvenile graves, and adult-juvenile graves). Among the ring graves, on the other 
Fig. 19. The cemetery at Michajlovskoe was probably originally much larger.

hand, all except one (10 of 11) are female graves. At Petrovskoe the material is so small that it is very difficult to accept the indications as conclusive. Both paws and rings are more common in the female graves although they also occur in male graves. At Michailovskoe the relationship is reversed. Paw graves as well as ring graves are most often male graves although a few female graves with these attributes are also found.

Just as we could observe that the find

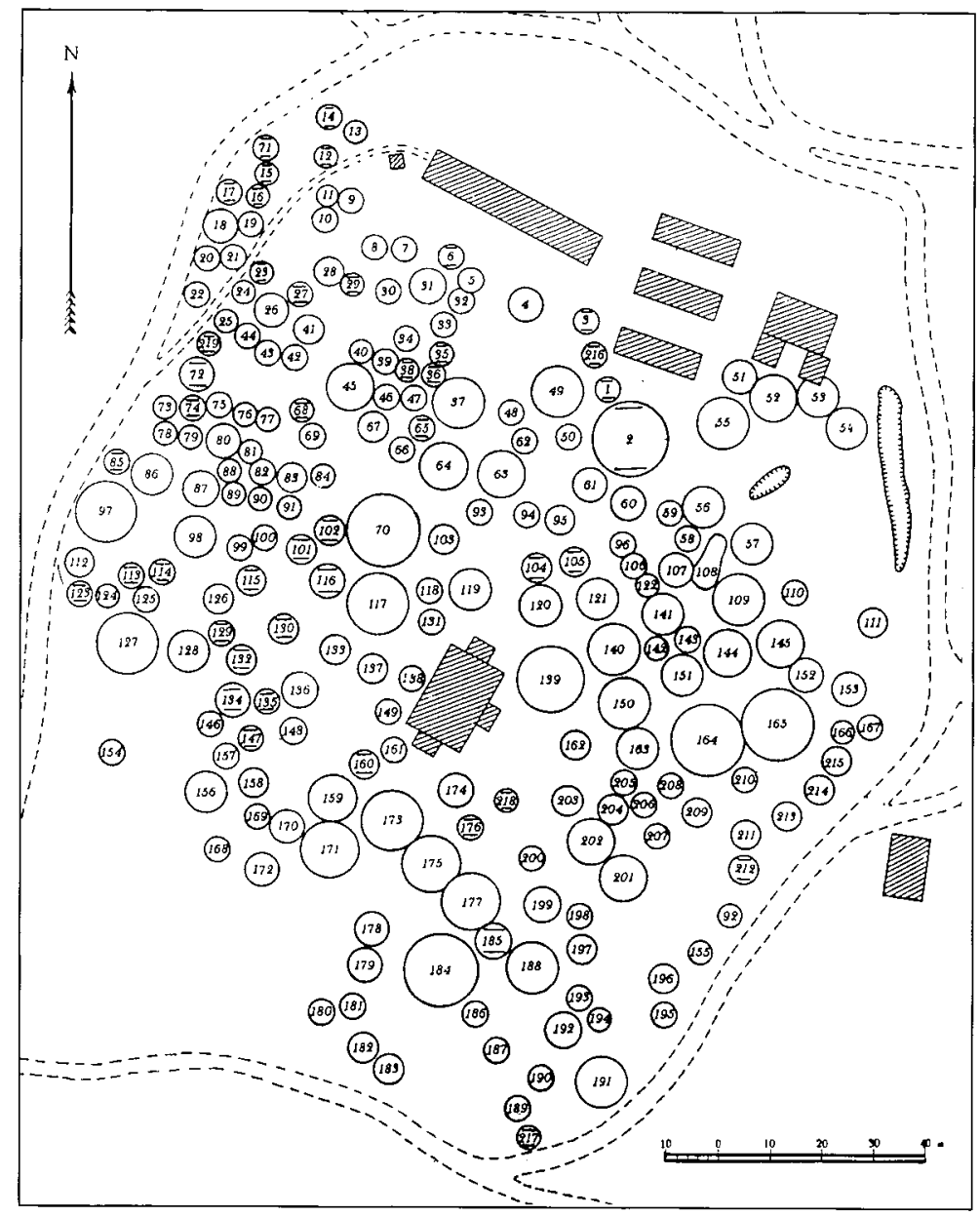
circumstances for the clay paws on Åland could indicate a division into two social territories, we can see tendencies to a similar division between the three settlements in the Jaroslavl' area. Certain social groups, most probably descent groups or clans have in a fixed, possibly largely exogamous pattern been connected in different ways to the three different settlements and cemeteries. Especially the occurrence of graves with clay rings shows a distinct pattern with considerable differences between Michailovskoe on the one hand and Petrovskoe and Timerevo on the other. As has been shown, the paw custom also has a special connection with Timerevo.

Another observation which could be made on the basis of the Alandic material could also be pursued further in the material from the three cemeteries in the Jaroslavl' area. On Alland we could see that a territorial division of the population led to the development of contacts of exchange character with the Finnish mainland for one group. The clay paw group or groups perhaps already at that stage maintained different contacts with other external groups, e.g. in connection with distant hunting-expeditions. Also in the Jaroslavl' area the different groups have different contact nets. Most remarkable in this connection is that finds 
like earspoons and earthenware vessels, which exhibit traits typical of the Vjatka - Kama area (perhaps most likely the Cepca basin), are much more common in clay paw graves than in other graves. In the Vjatka-Kama area specialized hunting for furs had a long tradition and was well developed (Goldina 1985: 150-2). It was probably from this direction that the clay paw population became acquainted with hunting-bows enforced with bone plates (Semenov 1980:46). Although not all finds of bow plates in the Jaroslavl' cemeteries are combined with paws, the proportion is considerably higher than among other cremation graves.

From the three settlements on the Volga the burial rites connected with the cremation graves spread southward to new areas (Fig. 18). We are concerned here with the regions around the two lakes Nero and Plesceevo and along the Nerl', a tributary of the river Kljaz'ma. At ten localities in these areas we find barrow cemeteries with cremation graves, and in several cases clay paws and clay rings have been found in the graves (Gorjunova 1961:192-4, Rjabinin \& Leont'ev 1982: $67 \mathrm{ff}$ ). All of these cemeteries could be dated to the tenth century. This movement of population groups with a grave rite which so closely parallels that at the three cemeteries must to a certain extent be interpreted as a colonization phase. It can, however, not only be understood as a simple extension of settlement. It is certainly intimately connected with the further experiences of the Merians.

The Merians as a separate population group become less distinct in the ninth and tenth centuries. This Finno-Ugric population, to judge from the archaeological material, partly becomes acculturated and absorbed in the population that constructed the new, exogenous, cremation-burial barrow cemeteries (Gorjunova 1961:183 f, Rjabinin \& Leont'ev 1982). Other Merian groups remain here and there in the area under rather unchanged cultural and social conditions up to the end of the tenth century (Golubeva 1987:74, 81).
However, the changed situation resulted partly in an exodus of the Merian population and perhaps also of other Finnish groups towards the north and the northeast. This movement led to a certain revival of the distinct Finnish cultural traits and perhaps also to a new ethnic identity (Rjabinin 1986).

The ethnic interpretation of these cemeteries as evidence mainly of Slavic and to a minor part Finno-Ugrian groups, as well as of a Slavic colonisation in the Volga area in the ninth and early tenth centuries, has made it very difficult to appreciate the essential character of the ninth- and tenth-century barrow cemeteries with cremations in the region between the Volga and the Kljaz'ma, and to understand the clay paw complex (cf. Bulkin \& Dubov \& Lebedev 1978:115 ff, Dubov 1978:134-5). It should not be denied that there have been tendencies to see the problems differently. Fechner's work is very important. She recognizes the early beginning of the settlements and maintains, probably correctly that a Slavic colonisation did not begin until the middle of the tenth century (1963A:17). The Scandinavian character of much of the material is, however, only partly acknowledged as is the Alandic connection (cf. above). Dubov's emphasis on the economical importance and the exclusive character of at least Timerevo and Petrovskoe has also been important, though it is combined with a traditional Slavic interpretation of the dominating ethnic elements (Dubov 1978, 1979, 1982).

When viewed today, the distribution pattern of find localities with clay paws appears to be very clearly concentrated to the Jaroslavl' area and adjacent areas further south down to the Kljaz'ma. Is this a completely reliable picture? It could be doubted for several reasons. A solitary clay paw found in a grave at Sestovicy in central Ukraine does not change the distribution picture very much. It should rather be interpreted in another way (cf. below). More thought-provoking is a find of a clay paw from a destroyed cemetery at 
Starica on the Volga, c. $90 \mathrm{~km}$ above Tver' (Pletnev 1903:116). Whether this was only a single grave featuring this special element, or whether there were several clay paw graves, cannot be ascertained today. In general we must, however, conclude that our knowledge of late ninth- and tenth-century cremation graves on the upper Volga is meager. The connection between clay paw graves and an important economical and political centre, at least at Timerevo, makes it important to consider whether there were people of the clay paw and clay ring groups at other centres. A recently identified ninth-tenth century settlement possibly of this type at Kreva near Kimry (Beleckij \& Krymov \& Frolov 1988) on the lower Dubna, a tributary of the Volga, is not studied well enough to answer the question. In the case of Gnezdovo, the important centre on the upper Dniepr, we may feel

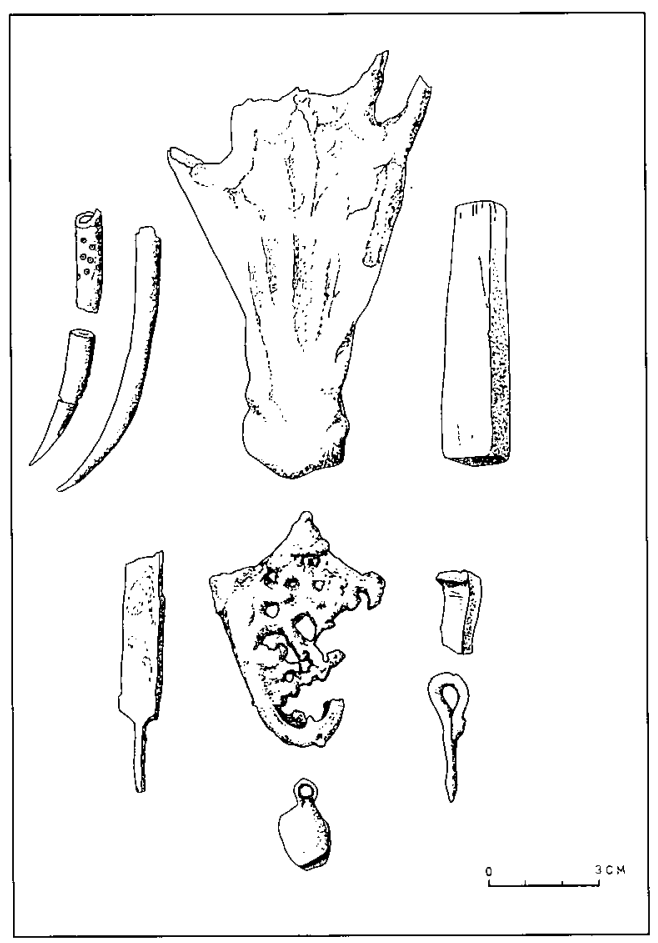

Fig. 20. A tenth-century cremation grave inventory from Bol'soe Timerevo with a clay paw (grave no. 274).

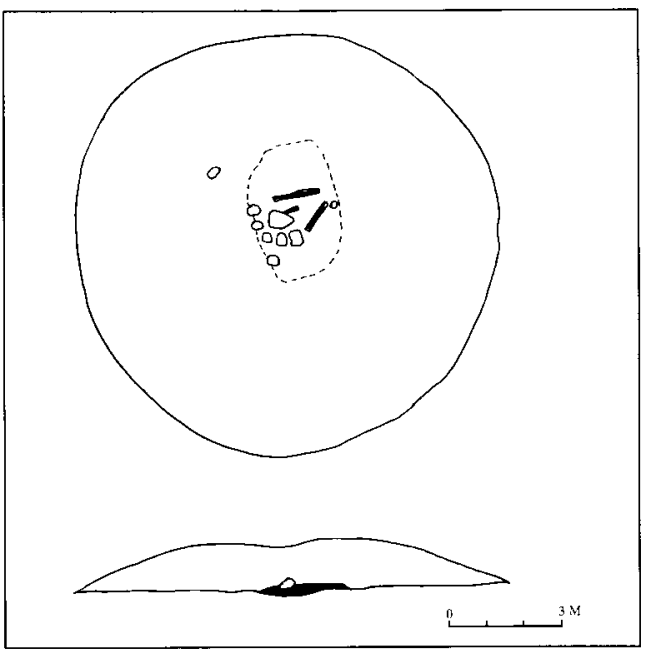

Fig. 21. A large barrow with a cremation grave at Bol'soe Timerevo (grave 85).

confident to state that at present no traces of clay paws or clay rings have been found among the hundreds of excavated graves. A definite sign of connections between the Merian lands and Gnezdovo is, however, the find of a grave with a complete set of Merian female ornaments (Kuscinskij 1881:5).

For the understanding of the clay paw graves in central Russia it would have been more important to be able to make comparisons with contemporaneous and earlier cemeteries at the centres of Novgorod (Rjurikovo Gorodisce) and Staraja Ladoga. Unfortunately the cemetery at Rjurikovo Gorodisce has not yet been found and may well have been completely destroyed. We shall probably never know whether there were clay paws here and, if so, in what proportion. The possibilities to complete the present very unclear picture are to a certain extent better at Staraja Lodoga. However, also there major parts of the cemeteries are destroyed, and only little effort has been made to excavate other graves than the local large tumuli, the sopki. Consequently, at present we cannot exclude the possibility that there have been clay paw burials at Staraja Ladoga and Rjurikovo Gorodisce, near Novgorod. Especially at Sta- 
raja Ladoga it is most likely that members of clay paw groups were also buried.

A remarkable find which illustrates very well the long-distance connections of the adherents of the clay paw rite is the occurrence of a clay paw in a cremation grave of tenth-century date at Sestovicy near Črnigov in central Ukraine (Blifel'd 1977). Sestovicy is a cemetery of a population that includes a partly Scandinavian warrior and administration group, and it features several very rich graves among which are chamber graves (ibidem: 20-3). the grave in question is a male grave furnished with two wheel-turned earthenware vessels of local type, and probably a pouch with a whetstone, flint and a fitting for tinder, as well as an antler point with an animal-head termination at the basal end (ibidem: 186-7). Several of the antler points of this type found in different parts och northern and eastern Europe have distinct animal heads with characteristic rodent teeth, presumably representations of beaver (cf. Schwarz-Mackensen 1976:20). The connection of these bone implements with a functional and/or symbolic procedure related to some stage in the handling of fur-bearing animals cannot be rejected.

The interpretation of the ninth- and tenthcentury settlement sequence in the Jaroslavl' area and in the region of the Volga and the Kljaz'ma is that there is evidence of an influx of an alien, mainly Scandinavian population group to the land of the Merians. This immigration is probably intimately connected with the exploitation of resources in the area, the most important being furs. This initial stage of influx is preceded by a period of intensified contacts with the Baltic region, including exchange. We can reckon with groups of Scandinavians possibly cooperating with trade specialists from northwestern Europe who penetrate the river systems of the Ilmen' basin and proceed into the drainage area of the upper Volga. The motives for these groups to operate over such considerable distances as already suggested were, without doubt, an interest in furs which could be exchanged for a number of luxury goods of southern origin or goods produced under the control of trade specialists. Slaves could also have been of some interest but the sparse population in the relevant areas is not indicative in that direction. Slaves had to be procured in areas further south.

After the middle of the ninth century economic interests in the central Russian area reached a level at which groups active in trade and exchange consider a permanent presence in the area to be advantageous. During the second half of the ninth century at least three large settlements are established at a short distance from the outlet of the Kotorosl ${ }^{\prime}$ in the Volga. The main character of these groups is Scandinavian and many but probably not all are immigrant Ålanders,

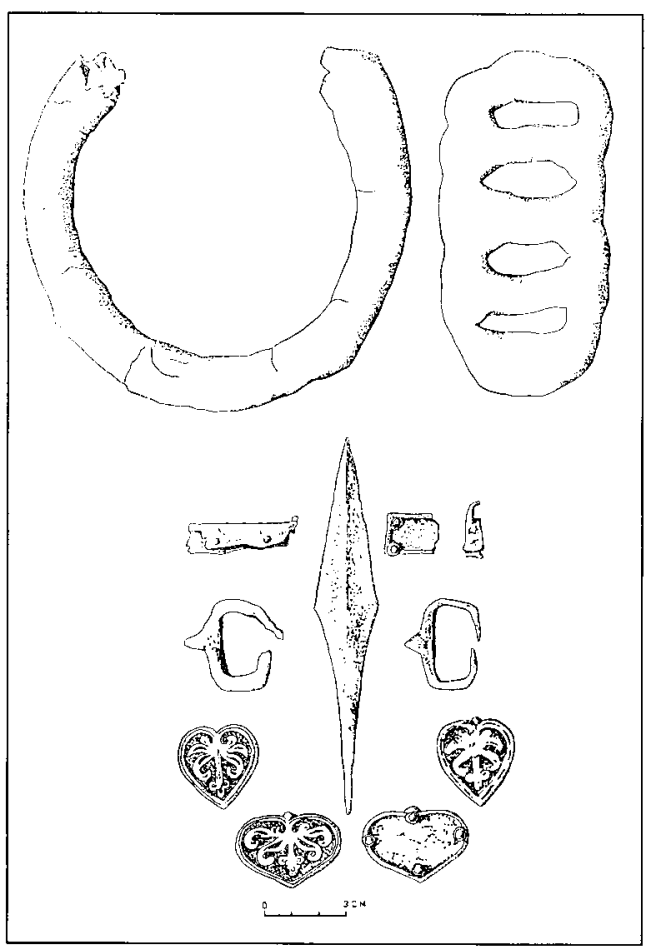

Fig. 22. A tenth-century cremation grave inventory from Michajlovskoe with a clay ring and another unique clay object (grave 1961:216). 
though it is highly probable that it is erronous to give these groups a too distinct and strict ethnic interpretation. With reference to the long experience of the Alanders of socially embedded contacts with Finnish groups, it is probable that they were highly capable of integrating individuals and families of other ethnic groups. The find material strongly suggests that this was the case. In an early phase we can note graves which indicate marriages between Scandinavian men and Merian women (Jaroslavskoe Povolže 1963: 130, 137). Later the Merian component in the material is supplemented with indications of close personal contacts with the Udmurtians on the Cepca.

When the settlements near the mouth of the Kotorosl' had been established, they soon developed a complex interrelationship featuring different magical and religious practices like the use of clay paws brought over from $\AA$ Aland and the use of clay rings, an innovation in the new settlements. There are also many new cultural traits common to the three settlements and best visible in the general character of the burial rite. The new cultural forms emerging as a consequence of the presence of the population in a new surrounding, mentally partly cut off from their original social milieu, obviously have both an integrative character and an internally differentiating character.

In the tenth century there is an expansion of this new type of settlement southward into the Lake Nero and Lake Plesceevo areas and even further south. At least ten new settlements are established, often close to Merian settlements.

The Merian population is partly integrated into the new social aggregates, partly withdraws eastward, and partly continues its traditional life up to the end of the tenth century (i.e. in areas without new alien settlements). During the later part of the tenth century, groups possibly featuring Slavic cultural traits appear in the central Russian area. Further studies of the later development in the

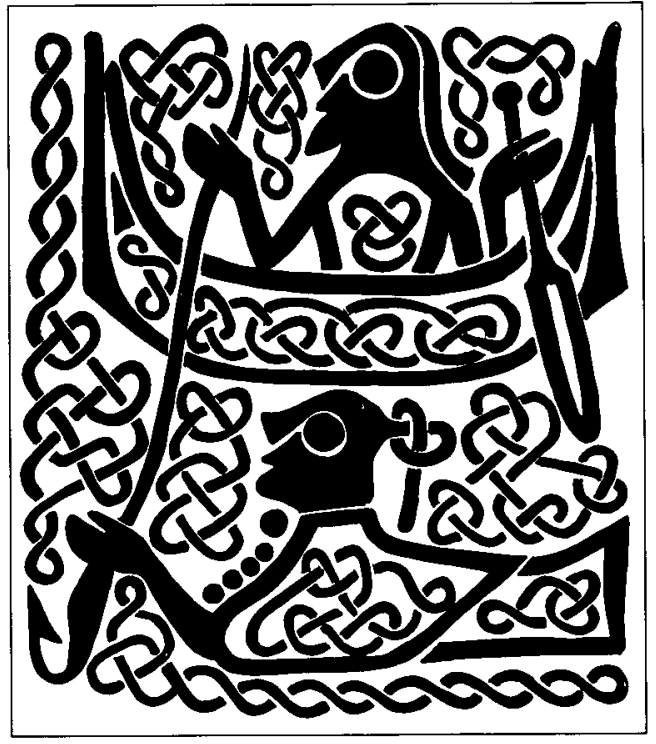

Fig. 23. Ascene from the Kalevala epos (Väinömöinen and Vellamo) from an eighth century mount found in a rich burial at Solberga, Askeby parish in the province of Östergötland, Sweden.

area are complicated by the fact that there are important changes in the archaeological material at the beginning of the eleventh century.

As we have seen, the clay paw and clay ring grave rites were used in central Russia in a somewhat different yet generally similar way to those on the Alland Islands. The ideas of the practitioners of the clay paw rite certainly through earlier generations had seen great changes and dynamic developments; but the sequence in central Russia, from the establishment of the three settlements up to the abandonment of the rites, was even more dramatic.

The three settlements may have been established first as centres for the fur trade, hunting-expeditions and tribute collecting. Very soon, however, ambitions had increased and many fertile key areas of central Russia were successively controlled and partly settled by the new groups. This process included the formation of structures of power and 
domination and above all the creation of new identities. People of diverse origins were successively integrated into a new society. The rites discussed here may have played an important role in identifying the actors in this political and economical change.

It is most likely that the clay paw and clay ring rites played a central role in this integration. Especially the creation of the clay ring element of the rite as some sort of parallel to the clay paw gives testimony of the innovative momentum of this process. At present the abandonment of the rite is difficult to explain. Obviously both the clay paws and the rings were intimately connected with the cremation of the dead. Like many other practices closely connected with cremation, they could not accord with the ideas connected with inhumation. The turn-over from cremation to inhumation is a phenomenon which can be followed throughout many parts of Russia from the last decades of the tenth century to the early decades of the eleventh. Among the Volga-Finnish population birituality was already known.

It may be enough at this point to conclude that the distribution area of the clay paw graves in central Russia already in the eleventh century formed part of one of the most important regions of Old Russia. The political importance of these parts rose even further and in the twelfth century already the princes of Vladimir and Suzdal' were among the politically strongest forces in the woodland zone. Later this part of Russia became the heartland of the state of Muscovy. It is obvious that this continuous development has its very beginning in the establishment of the three settlements near Jaroslavl' in the second half of the ninth century. It is one of the signifcant roots of historical Russia.

That there were still contradictions between traditions and beliefs during the eleventh century in central Russia, possibly some of them connected with groups already formed in the ninth and tenth centuries, is evident in the written sources. Short glimpses of the so- cial conditions in the area during the eleventh century are provided by the Primary Chronicle for the years A.D. 1024 and 1071. In both cases there are peasant uprisings against the elites triggered by periods of famine. Obviously the harvest of cereals was a failure and food had to be imported from outside the region, i.a. from Volgabulgaria. The frequent and catastrophal crop failures may indicate a rather young cultural landscape with little diversity. The chronicle makes it clear that heathen religion still plays an important role in the region during the second half of the eleventh century. Possibly elements of the population which were somehow connected with the clay paw and clay ring rites were still active at that date.

The lower strata in society, which are designated in the chronicle as smerdy and which were at least partly under the leadership of heathen "witch doctors", volchvy, took by force the food products stored in the houses of the elite in the region, which bore the special name staraja $\check{c} a d '$. With the closeness in dating between the cemeteries discussed and the entry sub Anno D. 1024 we can ponder whether the staraja cad' was indeed identical or closely related to some stratum of elites which we can distinguish in the archaeological material. For many reasons the population associated with the chamber graves of the tenth century could be seriously considered. This population was not connected with the clay paw and clay ring groups. It is then indeed not unlikely that people descended from these groups did take part in the uprisings. Clay paw graves never had an exclusively aristocratic character. As indeed expected from a cult community, it cut through the strata of society in another way. Groups including remnants of the clay paw and clay ring community may have taken part in the uprising on the, in reality, heathen smerdy side against the now Christian aristocratic elite.

The emergence of the clay paw rite on Alland sometime around A.D. 600 may be 
understood as a magical or more probably religious innovation under special conditions. The largely new population of the Åland Islands forms a new general cultural identity but also develops symbols which function as socially motivated markings of an inner differentiation. As we have seen, the clay paw rite with a high degree of probability can be connected with fur-bearing animals and especially with the beaver. If we accept this interpretation, and I think we must in the light of the strong physical likeness to real beaver paws and their context, the following sketch should be plausible. The beaver was, of course, not necessary for the subsistence of groups of the population. The beaver furs were, however, the sources of an inflow of exchange goods to the clay paw groups and certainly also to other parts of the Alandic society. The leaders of groups involved in the exploitation of fur-bearing animals obviously could display many attributes connected with traditional conspicious consumption in Scandinavian society. The general social system of the Scandinavian Late Iron Age with political leaders ( $\mathrm{Sw}$. stormän) contesting domination of larger areas, and with temporary federations and realms of low stability, is certainly apt to develop exchange connections with agents of trade which could supply parts of the paraphernalia that could greatly underline the position of the leading strata and help build necessary and desired alliances.

It would be a great mistake, however, to consider only this socially and economically perhaps also politically - rational explanation of the clay paw rite. The idea of the clay paw rite must have been much more intimately integrated into the mythological and religious beliefs of the population. The clay paw rite must have been part of a cult of which we have no traces in the literary sources of the medieval period dealing with the pagan religion. Before we go further we must also consider the possibility of existing local cults which are not documented or which have only left traces in a vague and transformed form. A comparative study of pagan religions is highly indicative of local cults. We may, for example, point out the numerous local cults known from Classical antiquity (cf. Nilsson 1925). The picture we have of Scandinavian pagan religion and myths from the Old Norse literary sources is, of course, not complete. The east Scandinavian cults and myths are largely unknown, although we can assume that many of the deities were the same.

Animal cults were not typical of the Old Scandinavian religion as we know it from the west Nordic, mostly Icelandic literary sources, and gods normally have a human appearance. Well documented is, however, the horse cult (Mathiessen 1945) and several other domestic animals obviously also play a role in the pagan cult. Wild animals in some cases may represent or symbolize deities and sometime gods take the shape of wild animals, e.g. otter or bird. For the Icelandic Viking Age and early medieval populations wild terrestrial mammals were of little importance and they had no or little experience of them (polar foxes and occasional polar bears). It is consequently not likely that the tradition of animal myths (dealing with mammals) was very active among the Icelanders, and many may have been forgotten.

A number of observations makes it certain that wild animals played an important role in the mythology and the religion of the Scandinavians in the Late Iron Age. Special ideas were connected with the brown bear. Already the taboo name of the animal shows its importance and its magical power (Holmberg 1923). The half-human character of the animal is obvious in later folkloristic material from Sweden and Finland. Of importance here are also the myths, including the union between male bears and women which led to the founding of important dynasties (cf. Saxo Grammaticus 1908-12, 15:10). As has been pointed out, these reflections of a bear cult cannot be separated from the 
widespread bear cult in northern Eurasia (Lot-Falck 1953).

Several physical traits of the beaver and several pecularities of its behaviour have throughout its distribution area attracted the attention of man and stimulated the imagination. The amphibious life of beaver and the total absence of exterior gender characteristics have led to mythological representations of beavers, or mythological figures featuring distinct beaver tratis. The dam-building activities of the beaver and expecially the construction of the beaver huts have also led to mythological tales. The wide spread and very strong beliefs in the healing power of the beaver gill must also be understood as an indication of more general ideas of the beaver as a powerful and important animal (Skalon 1950: 134-59).

Mythological ideas about the beaver as an important and potent actor in the cosmos of man are known from northern Eurasia and from North America (cf. Vecsey 1983). Myths which include intermarriage between women and beavers are also known in this case. Like the bear myths, they are evidently part of a myth-complex connected with peoples who were not necessarily exclusively huntergatherers but for whom these activities were of central importance e.g. the Aryans. Close to the Scandinavians there lived peoples for whom these animal myths and religious ideas connected with wild animals were more prominent. It is natural to think that the close contacts with the Finns among the eastScandinavians, especially on Aland but also probably earlier in the coastal regions of the Baltic, also resulted in a flow of myths in both directions which could have meant a reactivation of wild animal cults and wild animal myths among the Scandinavians (cf. Harva 1948, Krohn 1932). We are fortunate to have a piece of rather concrete evidence showing that this contact and myth exchange were real, although the myth in question is not connected with beavers. In a rich eighthcentury "big man`s" cremation grave excava- ted at Solberga, Askeby parish in Östergötland (mainland Sweden), there was found among the debris which must largely have been grave furniture resembling that of the boat graves of Vendel and Valsgärde a rectangular mount with a scene depicting a man fishing from a boat and a fish-woman on the hook (Arbman 1941:68-9). The motive is very clearly rendered and the scene can be put in direct connection with a passage in Kalevala, the Finnish mythological epos. It is the scene of Väinömöinen getting hold of the water mistress Vellamo (Lindquist 1945) (Fig. 23). If the Kalevala mythology and religious elements were well known in eastern middle Sweden, then other myths belonging to the Finns may have been widely spread too. Another connection with the East is the shamanistic trait in the Scandinavian pagan religion. Among the Finno-Ugrian peoples and among the Lapps, religious beliefs and myths are closely connected with shamanism. With the help of the shaman it is possible to come in close contact with gods, spirits, the master of the wild animals, etc. Shamanistic elements are especially connected with Odin (Pettersson 1972:275) but also appear in myths, e.g. the Völund myth (Vierck MS).

These remarks have suggested a mythological-spiritual milieu in which the clay paw rite probably should be understood as hunting-magic, but it may also have had a deeper religious meaning to the clay paw groups.

The clay rings deposited in the central Russian graves pose even more complicated problems than the paws since the ring symbol has such general significance with regard to both religious ideas and mythology. The central ideas connected with the ring symbol may be sorted out first. The magic circle and the ring, as a link between deity and man or between humans, have probably been well known to the inhabitants of the settlements connected with the central Russian cemeteries discussed here. The ring as a token of strong ties is well known from the Old Norse litera- 
ture, and a plausible piece of concrete evidence for the link between god and man is the so-called Thor's hammer rings which are so common in east Scandinavian graves (Ström 1984) which are also found in a number of graves at Timerevo and Michailovskoe (Fechner 1966). The magic circle can be exemplified by the traditional circular enclosure of barrows in Scandinavia and elsewhere. It may, however, be more fruitful to continue our discussion from another starting-point. In my opinion, the innovation of the clay ring element in the burial cannot be considered without appreciating its abovementioned complementary character in relation to the clay paw rite. It must be understood as a symbol with a significance which plays an important role for a population group that is part of the total population connected with the cemeteries. The clay ring probably should not be understood as a symbolic magic ring or circle. The appearance in the grave and the size of the object rather suggest the function of a symbol in close relationship with an important or powerful superhuman force. Whether this force was a deity of the anthropoid sort, an animal god or the master of the

\section{REFERENCES}

Ambrosiani, S. 1948. Bevillning och skatt på Åland före Gustav Vasa. Budkavlen, 1948. Mariehamn.

Andreeva, E.G. 1963. Fauna Jaroslavskogo Povolž ja po kostnym ostatkam iz kurgannych pogrebenij X-XI vv. Jaroslavskoe Povolźe. Moskva.

Arrhenius, B. 1960. En vendeltida smyckeuppsättning. Fornvännen. Stockholm.

Baudou, E. 1960. Fanns en fast bygd i Österbotten under vikingatid och korstågstid? Studia archaeologica ostrobothniensia, 1987. Vasa.

Beleckij, S.V.\& Krymov. E. Ju \& Frolov, A.S. 1988. Raboty $v$ okrestnostjach Dubny. Archeologiceskie otkrytija 1986 goda. Moskva. wild, is probably impossible to determine at present. The central importance which is connected with fur-bearing animals for the population could speak in favour of the rings being symbols for animal gods. It is important here to stress further the close connection between the paws and the rings which could be an indication in the same direction. The ring as a gift to the divine bear is known for example, among the Ugrian peoples (LotFalck 1953).

Whether the paws and rings should be discussed as totemistic symbols is very difficult to say. The two symbols are both probably strongly indicative of a very close relationship between animals of certain species and human groups. It seems very reasonable to maintain that the clay paw groups used the paws as a symbolic representation of the beaver and the bear which they worshipped. This strong and close relationship could very well have taken the form of a totemistic idea of the connection between man and animal.

English revised by Laura Wrang.

Blifel’d, D.I. 1977. Davnóorus ki pam jatky Šstovyci. Kiev.

Bulkin, V.A. \& Dubov, I.V. \& Lebedev, G.S. 1978. Archeologiceskie pamjatniki Drevnej Rusi $I X-X I$ vekov. Leningrad.

Callmer, J. 1982. Den yngre järnålderns keramik på Åland. (MS)

- (in prep.) Finno-ugrian imports to Sweden in the Vendel and Viking periods.

Delort, R. 1978. Le commerce des fourrures en Occident a la fin du Moyen Age (vers 1300vers 1450 ). Rome.

Dreijer, M. 1945. En åländsk fågelnål. Strena archaeological Professori A.M- Tallgren sexagenario dedicata. Finska fornminnesförening- 
ens tidskrift, XLV. Helsingfors.

- 1959. Lagneskärrsbacken och Kohagen. Aländsk odling, 1959. Mariehamn.

- 1979. Det åländska folkets historia, I:1. Mariehamn.

Dubov, I.V. 1978. Jaroslavskoe Povolže v X-XI vv. Archeologiteskie pamjatniki Drevnej Rusi $I X-X I v v$. Leningrad.

Dubov, V.I. 1982. Severovostocnaja Rus 'v epochu rannego srednevekov' $j a$. Leningrad

- 1979. Timerevskij kompleks protogorodskoj centr $\vee$ zone slavjano-finskich kontaktov. Finno-ugry i slavjane. Leningrad.

- 1984. Glinjanye lapy v pogrebal'nom obrjade kurganov Alandskich ostrovov i Volgo-Okskogo meždurec ‘ja. Novoe $v$ archeologii SSSR $i$ Finljandii. Doklady tret'ego sovetsko-finljandskogo simpoziuma po voprosam archeologii, 1981. Leningrad.

- 1988. Jaroslavskoe Povolže v IX-XIII vv (vedušçie issledovateli i osnovnye problemy). Slavjano-russkie drevnosti, I. Leningrad.

Dybeck, R. 1871. Undersökning i svenska forngravar. Runa, 1:4. Stockholm.

Eesti esiajalugu. 1982. Tallinn.

Fechner, M.V.- 1962. Glinjanye lapy iz Timerevskogo kurgannogo mogil’nika. Sovetskaja archeologija, 1962:3.

- 1963A. Timerevskij mogil'nik. Jaroslavskoe Povolžé Moskva.

- 1963B. Petrovskij mogil'nik. Jaroslavskoe Povolže. Moskva.

- 1963C. Vnešneekonomiceskie svjazi po materialam jaroslavskich mogil’nikov. Jaroslavskoe Povolźe. Moskva.

- 1963D. Predmety jazyceskogo kul'ta. Jaroslavskoe Povolže e. Moskva.

- 1966. O proischoždenii i datirovke železnych griven. Archeologiceskij sbornik. Trudy Gosudarstvennogo Istoriceskogo Muzeja, 40. Moskva.

- \& Janina, S.A. 1979. Vesy s arabskoj nadpis ju iz Timereva. Voprosy drevnej i sredneveko-voj archeologii Vostocnoj Evropy. Moskva.

- \& Nedosivina, I.G. 1987. Etnokul'turnaja charakteristika Timerevskogo mogil'nika po materialam progrebal'nogo inventar ja. Sovetskaja archeologija 1987:2. Moskva.

Glückert, G. 1978. Östersjöns postglaciala strandförskjutning och skogens historia på Åland. Turun Yliopiston maaperägeologian osaston julkaisuja, 34. Turku.
Goldina, R.D. 1985. Lomovatovskaja kul'tura. Irkutsk.

Golubeva, L. A. 1987. Merja. Finno-ugry i balty $v$ epochu srednevekov'ja. (Archeologija SSSR). Moskva.

Gorjunova, E.I. 1961. Etniðeskaja istorija Volgaokskogo meždurec ja. Materialy $i$ issledovanija po archeologii SSSR, 94. Moskva.

Hackman, A. 1902. Arkeologiska undersökningar på Åland sommaren 1901. Finskt museum, IX. Helsingfors.

Harva (Holmberg), U. 1948. Suomalaisten muinaisusko. Porvoo.

Holmberg, U. 1925. Jagdriten der nördlichen Völker Asiens und Europas. Journal de la Societé Finno-ougrienne, XLI:1. Helsingfors.

Iregren, E. 1977. Vårby och Vårberg, 11. Studie av kremerade människo- och djurbensmaterial från järnåldern. Stockholm.

- 1988. Finds of brown bear (Ursus arctos) in Southern Scandinavia - indications of local hunting or trade. Trade and exchange in prehistory. Studies in honour of Berta Stjernquist. Lund.

Jansson, I. 1987. Communications between Scandinavia and Eastern Europe in the Viking Age. Untersuchungen zu Handel und Verkehr der vor- und frühgeschichtlichen Zeit in Mittel und Nordeuropa, IV. Abhandlungen der Akademie der Wissenschaften in Göttingen, Philologisch-Historische Klasse, Dritte Folge, Nr 156. Göttingen.

Jaroslavskoe Povoľ̌e e. 1963. Moskva.

Jensen, A.E. 1966. Wettkampf-Parteien, Zweiklassen-Systeme und geographische Orientierung. Kulturanthropologie. Hrsg. v. W.E. Mühlmann \& E.W. Müller. Berlin.

Keller, O. 1909. Die antike Tierwelt. Leipzig.

Kivikoski, E. 1934. Eisenzeitliche Tontatzen aus Åland. Eurasia septentrionalis antiqua, IX. Helsinki.

- 1939. Svenskar i österled under 500-talet. Finskt museum, 46. Helsingfors.

- 1944. Zur Herkunft der Karelier und ihrer Kultur. Acta archaeologica, XV. København.

- 1964. Finlands förhistoria. Helsingfors.

- 1965. Magisches Fundgut aus finnischer Eisenzeit. Suomen museo, 1965. Helsinki.

- 1980. Långängsbacken. Ett gravfält från yngre järnåldern på Åland. Finska fornminnesföreningens tidskrift, 80. Helsingfors.

Krohn, K. 1932. Zur finnischen Mythologie, I. 
Folklore fellows communications, 104. Helsingfors.

Kuscinskij, M.F. 1881. Archeologiceskie issledovanija v Smolenskoj gubernii. Drevnosti, t. g:I. Moskva.

Leont'ev, A.E. 1981. Skandinaviskie vešč v kollekcii Sarskogo gorodiša. Skandinaviskij sbornik, XXVI. Tallinn.

- \& Rjabinin, E.A. 1980. Etapy i formy assimiljacii letopisnoj mery (postanovka voprosa). Sovetskaja archeologija, 1980:2. Moskva.

- \& Sidorov, V.V. \& Islanova, I.V. 1986. VolgoOkskaja ekspedicija v 1977-1983 gg. Kratkie soobšcenija Instituta archeologii ANSSSR, 188. Moskva.

Lindqvist, S. 1945. Fornsvenska bilder i Kalevala. Nordisk Tidskrift, 1945. Stockholm.

Lot-Falck, E. 1953. Les rites de chasse chez les peuples sibériens. Paris.

Makarov, N.A. 1986. Archeologiçeskie dannye o charactere kolonizacii Ruskogo Severa v XXIII vv. Sovetskaja archeologija, 1986:3.

Mal'm, V.A. 1963. Kul'tovaja i bytovaja posuda iz Jaroslavskich mogil'nikov, Jaroslavskoe Povol:́e. Moskva.

Malmer, M. 1962. Jungneolithische Studien. Lund.

Marr, N.Ja. 1934. Lingivisticeskie namecaemye epochi. Izbrannye raboty, T. III. Moskva.

Mathiessen, C.C. 1945. Hesten i nordisk myte og kult. Dansk vetrinaerhistorisk Aarbog, XII. København.

Meinander, C.F. 1973. Brobackan pyöreä solki. Honos Ella Kivikoski. Finska fornminnesföreningens tidskrift, 75 . Helsinki.

- 1977. Forntiden i svenska Österbotten. Svenska Österbottens historia, I. Vasa.

- 1979. Biarmy. Finno-ugry i slavjane. Leningrad. - 1985. Odin i Staraja Ladoga. Finskt Museum 92. Helsingfors.

Nazarenko, V.A. 1982. Normanny i pojavlenie kurganov v Priladožé. Severnaja Rus'i ee sosedi v epochu rannego srednevekov ja. Leningrad.

Nilsson, M.P. 1925. A History of Greek Religion. Lund.

Ouvaroff, A. 1875. Etude sur les peuples primitifs de la Russie. Les Meriens. Saint-Pétersbourg.

Palmgren, A. 1961. Studier över havsstrandens vegetation och flora på Aland. Helsinki.

Petersen, J. 1928.Vikingetidens smykker: Stavanger.

Petré, B. 1980. Björnfällen i begravningsritualen - statusobjekt speglande regional skinnhandel?
Fornvännen. Stockholm.

Pettersson, O. 1972. Tro och rit. Religionsfenomenologisk översikt. Stockholm.

Ramqvist, P. \& Müller-Wille, M. 1988. Regionale und überregionale Bedeutung des völkerwanderungszeitlichen Gräberfeldes von Högom, Medelpad, Nord-Schweden. Ein Vorbericht. Germania, 66. Mainz.

Pletnev, V.A. 1903. Ob ostatkach drevnosti $i$ stariny v Tverskoj gubernii. Tver'.

Renfrew, C. 1973. Before Civilization: the radiocarbon revolution and prehistoric Europe. London.

Rjabinin, E.A. 1986. Kostromskoe Povolźe v rannem srednevekov'e. Moskva.

Roeck-Hansen, B. 1991. Township and territory. A study of rural land-use and settlement patterns in Åland c. A.D. 500-1550. Stockholm.

Rouse, I. 1986. Migrations in prehistory. Inferring population movement from cultural remains. New Haven.

Saxo Grammaticus (1908-12) Gesta Danorum. Utg. J. Olrik. København.

Schwarz-Mackensen, G. 1976. Die Knochennadeln von Haithabu. Berichte ïber die Ausgrabungen in Haithabu, 9. Neumünster.

Sedov, V.V. 1953. Etniceskij sostav naselenija severo-zapadnych zemel' Velikogo Novgoroda (IX-XIV vv.). Sovetskaja archeologija, XVIII. Moskva.

- 1970. Novgorodskie sopki. Archeologija SSSR. Svod archeologiteskich istotnikov, E1-8. Moskva.

Selinge, K.-G. 1977. Järnålderns bondekultur i Västernorrland. Västernorrlands förhistoria. Motala.

Semenov, V.A. 1980. Varninskij mogil’nik. Novyj pamjatnik polomskoj kul'tury. Iševsk.

Skalon, V.N. 1951. Recnye bobry Svernoj Azii. Moskva.

Smirnova, L.I. 1987. Lepnaja keramika Timerevskich kurganov i problema etniceskoj atribucii. Sovetskaja archeologija, 1987:2. Moskva.

Spicyn, A. 1896. Kurgany S.-Peterburgskoj gub.v raskopkach L.K. Ivanovskogo. Materialy po archeologii Rossii, No. 20. Petersburg.

Stankevic, Ja.V. 1941. Kvoprosu ob etniçeskom sostave naselenija Jaroslavskogo Povolž ja v IX-X st. Materialy i issledovanija poarcheologii SSSR, 6. Leningrad.

Ström, K. 1984. Thorshammerringe und andere Gegenstände des heidnischen Kults. Birka, II:1 . 
Stockholm.

Tret jakov, P.N. 1970. U istokov drevnerusskoj narodnosti. Materialy $i$ issledovanija po archeologii SSSR, 179. Moskva.

Watson, O.M. 1972. Symbolic and expressive uses of space: an introduction to proxemic behaviour. Reading.

Vecsey, C. 1983. Traditional Ojibwa Religion and Its Historical Changes. Philadelphia.

Vierck, H. (manuscript) Der beflügelte Schmied. Berlin.

Voionmaa, V. 1913. Studier i Ålands medeltids- historia. Finska fornminnesföreningens tidskrift, 27. Helsingfors.

Voronin, N.N. 1941. Medvežij kul`t v Verchnem Povolže $\mathrm{e}$ XIv. Materialy $i$ issledovanija po archeologii SSSR, 6. Leningrad.

Vuorela, T. 1964. The finno-ugric peoples. Bloomington.

Abbreviations

FNM National Museum of Finland (deposition in Mariehamn, ̊land).

$\AA ̊$ LM The Åland Museum (Mariehamn, Åland). 